\title{
On the capacity of ozonation to remove antimicrobial compounds, resistant bacteria and toxicity from urban wastewater effluents
}

\author{
I. Michael-Kordatou a , R. Andreou ${ }^{a}$, M. Iacovou ${ }^{a}$, Z. Frontistis ${ }^{\text {a,b }}$, E. Hapeshi ${ }^{\text {, }}$, C. Michael $^{\text {a }}$, \\ D. Fatta-Kassinos ${ }^{\mathrm{a}, *}$
}

a Department of Civil and Environmental Engineering and Nireas-International Water Research Centre, School of Engineering, University of Cyprus, P.O. Box 20537, 1678 Nicosia, Cyprus

b Department of Chemical Engineering, University of Patras, Caratheodory 1, University Campus, GR-26504 Patras, Greece

\section{H I G H L I G H T S}

- Erythromycin and ethylparaben were rapidly eliminated within $2 \mathrm{~min}$ at low $\mathrm{O}_{3}$ doses.

- 5 Transformation products (TPs) were identified retaining the ERY lactone ring.

- EtP structural alterations took place at the ethyl ester chain yielding 15 TPs.

- Phytotoxicity can be attributed to the organic matter and its oxidation products.

- ERY- and EtP-resistant E. coli were eliminated after $15 \mathrm{~min}$ of ozonation.

\section{A R T I C L E I N F O}

\section{Article history:}

Received 14 December 2015

Received in revised form 6 February 2016

Accepted 9 February 2016

Available online 11 February 2016

\section{Keywords:}

Antimicrobials

Bacterial resistance

Ozonation

Phytotoxicity

Transformation products
G R A P H I C A L A B S T R A C T

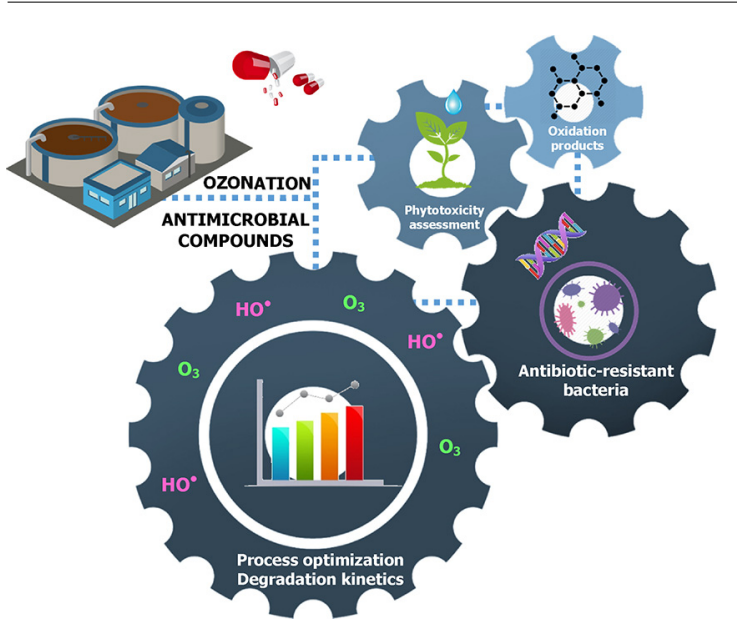

\begin{abstract}
A B S T R A C T
The degradation of erythromycin (ERY) and ethylparaben (EtP) in urban wastewater effluents at low concentration level during ozonation was investigated under different experimental conditions. Both substrates were rapidly eliminated within $2 \mathrm{~min}$ at low ozone dose of $0.3 \mathrm{mg} \mathrm{L}^{-1}$ and the experimental data were well fitted in the pseudo-first-order kinetic model. The ratio of $\mathrm{HO}^{\bullet}$ - and $\mathrm{O}_{3}$-exposure $\left(R_{c t}\right)$ at the inherent $\mathrm{pH}$ was found to be $1.9 \times 10^{-8}$. The degradation of ERY and EtP was pronounced at $\mathrm{pH} 8$ compared to acidic $\mathrm{pH}$ conditions, while the degradation rate of both substrates was found to be matrixdepended. It was also shown that both $\mathrm{O}_{3}$ - and $\mathrm{HO}^{\bullet}$-mediated pathways are involved in the degradation of EtP, whereas the saturated-rich structure of ERY renders it $\mathrm{O}_{3}$-recalcitrant. Under the optimum $\mathrm{O}_{3}$ dose, the $\mathrm{BrO}_{3}{ }^{-}$concentration was found to be lower than $10 \mu \mathrm{g} \mathrm{L}^{-1}$. Five and fifteen transformation products were elucidated during ERY and EtP oxidation, respectively. The root and shoot inhibition can be attributed to the oxidation products formed upon dissolved effluent organic matter transformation. Escherichia coli harbouring resistance to ERY survived ozonation better than EtP-resistant E. coli. However, neither ERY- nor EtP-resistant E. coli were detected after 15 min of ozonation.
\end{abstract}

(C) 2016 Elsevier B.V. All rights reserved.

\footnotetext{
* Corresponding author.

E-mail address: dfatta@ucy.ac.cy (D. Fatta-Kassinos).
} 


\section{Introduction}

Whilst wastewater reuse is nowadays considered as an indispensable practice to cope with water scarcity, a number of wastewater "quality" challenges are associated with this practice [1]. The ubiquitous occurrence of antimicrobials in conventionally treated wastewater effluents, e.g. antibiotics [2] and preservatives used in various formulations of personal care products such as parabens $[3,4]$, elevates the environmental and human health significance of this problem considering their potential biological effects.

The selective pressure exerted by antibiotics' improper use has been the major driving force behind the emergence and spread of antibiotic-resistant bacteria and resistance genes (ARB\&ARG) in both medical settings and environmental compartments [5]. Even though bacteria are continuously exposed to sub-inhibitory concentration levels of antibiotics in wastewater, recent evidence suggests that these levels can indeed impose selective pressure on ARB [6]. However, the potential of sub-inhibitory levels of antibiotics to select ARB can be limited given the complexity of the wastewater environment [7]. In addition, although the knowledge on the contribution of biocides (e.g. parabens) in antibiotic resistance is scanty, the Scientific Committee on Emerging and Newly Identified Health Risks of the EU [8] pointed out that prolonged exposure of bacteria to these compounds can also select for biocideresistant strains. To date, only one study has reported the presence of paraben-resistant bacteria in urban wastewater effluents [9]. Since conventional activated sludge (CAS) treatment can promote the horizontal gene transfer of antibiotic resistance among bacteria, it can be postulated that wastewater treatment facilities could create a potential risk of development of cross-resistance (i.e. the presence of one resistance mechanism that counteracts two or more antibacterial agents) between antibiotics and biocides.

Three macrolide antibiotics (i.e. erythromycin, clarithromycin and azithromycin), have been recently selected for inclusion in the EU Watch List of substances known to potentially pose environmental implications to the aquatic environment [10]. Among these, erythromycin (ERY) has been shown to significantly inhibit the photosynthesis-related processes of aquatic organisms even at $\mu \mathrm{g} \mathrm{L}^{-1}$ concentrations [11], while acute and chronic toxic effects of this antibiotic towards various species have been reported $[12,13]$.

Parabens have been shown to possess endocrine disrupting activity [14] exhibiting both estrogenic- [15] and antiandrogeniclike properties [16,17]. Moreover, a potential relationship between breast cancer and prolonged skin exposure to paraben-containing products was speculated, since in vitro studies provided evidence of intact parabens being present in human breast cancer tissue $\left(20.6 \pm 4.2 \mathrm{ng} \mathrm{g}_{\text {tissue }}^{-1}\right)$ [18]. Even though this hypothesis has not been verified and additional studies are needed to confirm their potential carcinogenicity, a new generation of paraben-free cosmetic products has emerged in the market recently to appease public concern. Despite the numerous reports on their estrogenic activity, few studies were conducted to assess the toxic effects exerted by parabens towards various aquatic organisms with the lowest-observed-effect concentration (LOEC) values being in the range of $\mu \mathrm{g} \mathrm{L}^{-1}$ to $\mathrm{mg} \mathrm{L}^{-1}$ depending on the type of organism and exposure conditions $[3,19,20]$.

Over the last decades, a great deal of interest has been focused on the application of ozone-based systems from laboratory to pilot- and later on to full-scale studies, which have been demonstrated to be effective in achieving significant abatement ( $>90 \%$ ) of various microcontaminants, while also providing sufficient disinfection of wastewater at reasonable specific ozone doses (e.g. $\left.g_{o s} / g_{D O C}=0.5-1\right)$ and short contact times [21-24]. Ozone can react directly or via a hydroxyl radical-mediated mechanism [25] with certain microcontaminants prevailing in the dissolved effluent organic matter $\left(\mathrm{dE}_{\mathrm{f}} \mathrm{OM}\right)$, resulting in the generation of new organic entities, which in some cases can be more biologically active than the compounds originally present in $\mathrm{dE}_{\mathrm{f}} \mathrm{OM}$ [26]. According to the authors' knowledge, a limited number of studies is available in the literature, dealing with the degradation of ERY $[27,28]$ and ethylparaben (EtP) [29] by ozonation. Ternes et al. [27] reported that $92 \%$ degradation of ERY $\left(0.62 \mu \mathrm{g} \mathrm{L}^{-1}\right)$ was achieved at $\mathrm{O}_{3}$ doses ranging between 5 and $15 \mathrm{mg} \mathrm{L}^{-1}$, while the removal of ERY $\left(40 \mathrm{mg} \mathrm{L}^{-1}\right)$ exceeded $99 \%$ within $45 \mathrm{~min}$ at $\mathrm{O}_{3}$ rate of $0.17 \mathrm{~g}_{\mathrm{O}_{3}} \mathrm{~min}^{-1}$. Tay et al. [29] determined the second-order rate constants during the degradation of parabens (including EtP) by ozonation. Nevertheless, ecotoxicological evaluation of the treated flow and assessment of the process in inactivating bacteria harbouring resistance to ERY and EtP have not been addressed in these studies.

For this purpose, a systematic study on the evaluation of the performance of ozonation in removing ERY and EtP present in secondary wastewater effluents at low concentration level $\left(100 \mu \mathrm{g} \mathrm{L}^{-1}\right)$ was carried out. An experimental methodology was put into place to assess the effect of various operating parameters on the removal and degradation rate of the substrates. Under the optimum experimental conditions, the contribution of both $\mathrm{O}_{3}$ and $\mathrm{HO}^{\bullet}$ in ERY and EtP degradation was determined. Also, bromate $\left(\mathrm{BrO}_{3}{ }^{-}\right)$formation was determined under various $\mathrm{O}_{3}$ doses and $\mathrm{pH}$ values. The main transformation products (TPs) derived from the oxidation of each substrate during ozonation were tentatively elucidated. A phytotoxic evaluation of the treated samples was carried out given that wastewater was taken from a treatment plant whose treated wastewater is reused in agricultural irrigation. Finally, the feasibility of the ozonation process in eliminating Escherichia coli that are resistant to ERY and EtP was evaluated. This is an assessment performed for the first time according to the authors' knowledge. Given the increasing interest in reusing treated wastewater and the fact that ozonation finds an increasing application acceptance during the last years, this paper constitutes the first integrated approach regarding the evaluation of the efficiency of this treatment technology to remove selected antimicrobials, $\mathrm{dE}_{\mathrm{f}} \mathrm{OM}$, phytotoxicity and resistant bacteria.

\section{Materials and methods}

\subsection{Chemicals}

Reference standards for the selected compounds (ERY [CAS number: 114-07-8] and EtP [CAS number: 120-47-8]) were purchased from Sigma Aldrich. Anhydrous sodium sulfite (Sigma Aldrich) was used to quench the reactions in each sample for the chromatographic analysis and for the determination of the dissolved organic carbon (DOC). $\mathrm{O}_{3}$ trap relying on the reaction of $\mathrm{O}_{3}$ with potassium iodide (KI, Fluka) was used for the decomposition of gas $\mathrm{O}_{3}$. Potassium indigo trisulfonate (Sigma Aldrich), sodium dihydrogen phosphate (Fluka) and phosphoric acid (85\%, Fluka) were used for the preparation of the indigo solution [30]. Humic acid (HA) was obtained from Sigma Aldrich. tert-butyl alcohol ( $t$ $\mathrm{BuOH}$ ) was supplied by Sigma Aldrich and used to suppress $\mathrm{HO}^{\bullet}$ reactions allowing thus only reactions with $\mathrm{O}_{3}$ to take place. For the chromatographic analysis, LC/MS-grade $\mathrm{MeOH}$ (Sigma Aldrich) and formic acid (98\%, Fluka) were used. $p$-chlorobenzoic acid ( $p C B A$, Sigma Aldrich) was used as a probe compound for the determination of $\mathrm{HO}^{\bullet}$ in the treated samples. The $\mathrm{pH}$ of the treated solutions intended for phytotoxicity and microbiological analyses was adjusted to $7 \pm 0.5$ using $2 \mathrm{~N} \mathrm{NaOH}$ solution (Merck). Tryptone Bile X-Glucuronide (TBX) medium agar (Sigma Aldrich) was used for the enumeration of $E$. coli.

Wastewater samples were collected downstream of CAS treatment (i.e. secondary clarifier) with their main qualitative 
characteristics being as follows: $\mathrm{pH}$ 7.8-8.0; conductivity= $1400-1465.6 \mu \mathrm{S} \mathrm{cm}^{-1} ; \mathrm{COD}=42-49 \mathrm{mg} \mathrm{L}^{-1} ; \mathrm{DOC}=7.9-11 \mathrm{mg} \mathrm{L}^{-1}$; TSS $=19-30 \mathrm{mg} \mathrm{L}^{-1}$; total- $\mathrm{N}=19.7-25.4 \mathrm{mg} \mathrm{L}^{-1}$ and total$\mathrm{P}=4.5-6 \mathrm{mg} \mathrm{L}^{-1}$. During the experimental period, the inherent concentration of ERY in the secondary treated wastewater samples fluctuated between 24 and $40 \mathrm{ng} \mathrm{L}^{-1}$, whereas EtP concentration between 105 and $160 \mathrm{ng} \mathrm{L}^{-1}$.

\subsection{Ozonation setup and procedure}

The selected compounds were individually spiked in wastewater from a prepared stock aqueous solution $\left(20 \mathrm{mg} \mathrm{L}^{-1}\right)$ at concentration of $100 \mu \mathrm{g} \mathrm{L}^{-1}$. The hydrolytic stability of each stock solution was routinely evaluated through chromatographic analysis after storage in a refrigerator for 0.5 month and it was found to be stable. Ozonation of the wastewater samples was performed in a cylindrical glass reactor of $1 \mathrm{~L}$ purchased from Ace Glass (Vineland, NJ, USA) operated in batch mode. $\mathrm{O}_{3}$ was produced by a corona discharge ozonator (LAB2B model, Triogen, Ozonia) fed by a pure oxygen generation unit. The production of $\mathrm{O}_{3}$ was controlled by altering the power input of $\mathrm{O}_{3}$ generator and adjusting oxygen gas flow by a valve. Aqueous $\mathrm{O}_{3}$ stock solution $\left(15 \mathrm{mg} \mathrm{L}^{-1}\right)$ was prepared by sparging gas $\mathrm{O}_{3}$ into ultrapure water placed inside a water jacketed beaker. Each run was initiated by injecting a predetermined volume of $\mathrm{O}_{3}$ saturated aqueous solution in the reactor vessel under vigorous stirring, necessary to achieve the desired initial oxidant concentration in the range of $0.1-0.5 \mathrm{mg}_{\mathrm{O}_{3}} \mathrm{~L}^{-1}$. Excess $\mathrm{O}_{3}$ was passed into a gas absorption bottle containing $2 \% \mathrm{KI}$ solution. For the competition kinetics experiments, $p C B A$ was also introduced into the reactor to yield a concentration of $0.5 \mu \mathrm{M}$ and was simultaneously oxidized with the compounds under investigation.

During the experimental runs, samples were withdrawn from the reactor at frequent time intervals and transferred immediately in glass vials with excess of $2 \mathrm{~N} \mathrm{Na}_{2} \mathrm{SO}_{3}$ solution in order to remove any residual $\mathrm{O}_{3}$. The samples were subsequently filtered $(0.22 \mu \mathrm{m})$ prior to further analysis. A relatively high initial substrate concentration ( $10 \mathrm{mg} \mathrm{L}^{-1}$ ), although not environmentally relevant, was applied in the experiments for the purpose of identifying the major TPs formed upon the oxidation of the parent compounds. Each experiment was performed in triplicate and mean values are quoted as results. The error bars depicted in the figures represent the relative standard deviation (RSD) of three independent measurements derived from three experimental runs. RSD values were always below $10 \%$.

\subsection{Analytical determinations}

The concentration of each compound in the treated samples was monitored through an ACQUITY TQD UPLC-MS ${ }^{2}$ system (Waters). Chromatographic separation of the analytes was achieved on an BEH Shield RP18 column $(1.7 \mu \mathrm{m} ; 2.1 \times 50 \mathrm{~mm}$; Waters $)$ with the mobile phase consisting of water $+0.1 \%$ formic acid (eluent A) and methanol (eluent B). The gradient elution progressed as reported in Michael-Kordatou et al. [31]. Multiple-reaction monitoring mode (MRM) was employed recording the transitions between the precursor ion (ERY: $m / z$ 734.7; EtP: $m / z$ 167) and the most abundant fragment ions (ERY: $m / z 158$ and 576; EtP: $m / z 95$ and 139). The LC-MS ${ }^{2}$ analysis conditions were: $\mathrm{T}_{\text {column }}=40^{\circ} \mathrm{C}$, flow rate $=0.3-0.4 \mathrm{~mL} \mathrm{~min}^{-1}$, cone voltage $=35 \mathrm{~V}$, injection volume $=10 \mu \mathrm{L}$ and run time $=9 \mathrm{~min}$. The TPs generated during treatment were pre-concentrated by means of off-line solidphase extraction (SPE) using Oasis HLB cartridges (Waters) [31], prior to analysis. All MS data was processed using the software package MassLynx V4.1.
High-performance liquid chromatography (Alliance 2695, UV detector 2689, Waters) equipped with a C-18 XBridge $^{\mathrm{TM}}$ column $(3.5 \mu \mathrm{m} ; 4.6 \times 250 \mathrm{~mm})$ was used to monitor the concentration of pCBA $(\lambda=234 \mathrm{~nm})$. An isocratic method comprising a mixture of $55 \% \mathrm{MeOH}$ and $45 \% 10 \mathrm{mM} \mathrm{H}_{3} \mathrm{PO}_{4}$ solution was employed at a flow rate of $1 \mathrm{~mL} \mathrm{~min}^{-1}$ according to the method reported by Elovitz and von Gunten [25].

DOC was determined using an Aurora 1030W TOC analyser. The dissolved $\mathrm{O}_{3}$ concentration in the liquid phase was determined by the indigo method [32]. The formation of $\mathrm{BrO}_{3}{ }^{-}$in the reaction solution was determined via ion chromatographic analysis (EPA 317.0, Metrohm 881, Compact ICpro).

\subsection{Phytotoxicity assay}

Phytotoxicity evaluation of the samples taken at various times of ozonation was conducted with the Phytotestkit microbiotest kit (MicroBioTests Inc.). The steps and procedure followed are extensively described in Michael et al. [33].

\subsection{Enumeration of total cultivable, ERY-and EtP-resistant E. coli}

A membrane filtration apparatus was used for E. coli enumeration as described elsewhere [33]. The oxidation experiments were performed at the optimum $\mathrm{O}_{3}$ dose in the presence of both ERY and EtP. The diluted treated samples $(\mathrm{NaCl}, 0.85 \%)$ were filtered through mixed cellulose ester gridded membranes $(0.45 \mu \mathrm{m}$, Millipore) and then the membranes were placed onto the TBX agar or on TBX medium impregnated with ERY or EtP and incubated for $24 \mathrm{~h}$ at $44{ }^{\circ} \mathrm{C}$. The concentration of ERY in the culture medium was chosen to be $100 \mu \mathrm{g} \mathrm{L}^{-1}$ based on its minimum inhibitory concentration (MIC) to E. coli [34]. Considering the lack of data regarding the MIC of EtP to E. coli and based on the MIC values reported for various antibiotics, two different EtP concentration levels were examined (i.e. $100 \mu \mathrm{g} \mathrm{L}^{-1}$ and $1 \mathrm{mg} \mathrm{L}^{-1}$ ). After the incubation period, the blue-coloured colony forming units (CFU) on the TBX agar were counted. The resistance percentage (R\%) was calculated by directly comparing the counts of $\mathrm{CFU} \mathrm{mL} \mathrm{m}^{-1}$ observed on the ERY or EtP supplemented culture medium with the corresponding counts on the control plate (i.e. medium without ERY or EtP). All microbiological analyses were made in triplicate for each sample.

\section{Results and discussion}

\subsection{Degradation of ERY and EtP during ozonation under various experimental conditions}

\subsubsection{Effect of $\mathrm{O}_{3}$ initial dose on the degradation of ERY and EtP}

The primary step of this study was focused on the evaluation of the reactivity of ERY and EtP towards $\mathrm{O}_{3}$ and the determination of the optimum oxidant dose required for their efficient removal. A series of experiments was carried out under different $\mathrm{O}_{3}$ doses, while the initial concentration of the target substrates was kept constant $\left([S]_{0}=100 \mu \mathrm{g} \mathrm{L}^{-1}\right.$, where $S$ stands for ERY or EtP). Based on the findings of previous studies $[27,35,36]$ which have shown that the oxidation of various microcontaminants during ozonation proceeds with high reaction rates, the amount of dissolved $\mathrm{O}_{3}$ used herein was maintained sufficiently low $\left(\left[\mathrm{O}_{3}\right]_{0}=0.1-0.5 \mathrm{mg} \mathrm{L}^{-1}\right)$, in order to provide favourable conditions for the easy and accurate determination of the tested compounds in the treated samples. Moreover, taking into account that the experiments were conducted at the inherent $\mathrm{pH}$ of the wastewater effluents ( $\mathrm{pH} 8$ ), it can be assumed that the substrates' degradation was predominantly driven by $\mathrm{HO}^{\bullet}$, rather than the direct reaction with molecular $\mathrm{O}_{3}$.

Fig. 1 shows the degradation profiles of the parent compounds as a function of reaction time and $\mathrm{O}_{3}$ initial concentration. The 

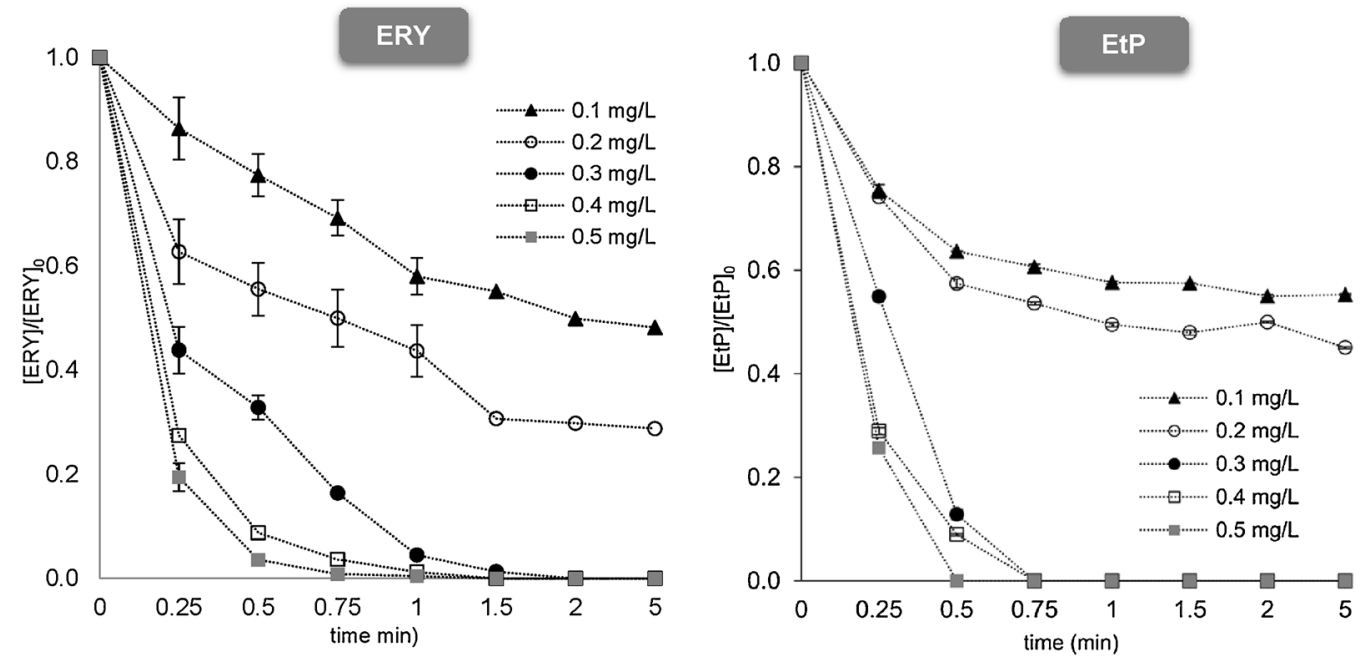

Fig. 1. Effect of ozone concentration on the degradation of ERY and EtP spiked wastewater solutions. Experimental conditions: $[S]_{0}=100 \mu \mathrm{g} \mathrm{L}^{-1} ; \mathrm{pH} 8$; $\mathrm{T}=25 \pm 2{ }^{\circ} \mathrm{C}$.

results revealed that both compounds were rapidly eliminated within 2 min of contact time when the initial $\mathrm{O}_{3}$ dose was in the range of $0.3-0.5 \mathrm{mg} \mathrm{L}^{-1}$, while further observation showed that the substrates' degradation gradually increased with increasing the $\mathrm{O}_{3}$ dose applied. The degradation of the substrates was hindered at lower $\mathrm{O}_{3}$ doses (i.e. 0.1 and $0.2 \mathrm{mg} \mathrm{L}^{-1}$ of $\mathrm{O}_{3}$ led to $45-52 \%$ and $55-71 \%$ degradation of ERY and EtP, respectively), indicating the strong interferences exerted between $\mathrm{dE}_{\mathrm{f}} \mathrm{OM}$ and $\mathrm{HO}^{\bullet}$ in the reaction solution. The results presented herein are consistent with those reported in previous studies on the removal of various pharmaceuticals during ozonation. Rivas et al. [37] showed that the degradation of ranitidine was enhanced in the presence of higher $\mathrm{O}_{3}$ doses, while it was found that $10 \mathrm{mg} \mathrm{L}^{-1}$ of $\mathrm{O}_{3}$ were sufficient to achieve a complete degradation of the compound. In studying the removal of a wide range of pharmaceuticals from wastewater effluents under various $\mathrm{O}_{3}$ doses ranging between $0.5-12 \mathrm{mg} \mathrm{L}^{-1}$, Antoniou et al. [36] observed the different susceptibility of the examined compounds towards $\mathrm{O}_{3}$, while at the same time, $\mathrm{O}_{3}$ dose requirement was found to vary significantly between effluents' characteristics. Ozonation of a wastewater solution containing sulfonamide and macrolide antibiotics (each of $40 \mathrm{mg} \mathrm{L}^{-1}$ ) resulted in complete degradation of all compounds within $20 \mathrm{~min}$, with ERY degradation being the slowest [28]. Snyder et al. [38] reported that ERY ( $\left.285 \mathrm{ng} \mathrm{L}^{-1}\right)$ was removed by $99 \%$ in tertiary treated wastewater during ozonation $\left(\left[\mathrm{O}_{3}\right]_{0}=4.6 \mathrm{mg} \mathrm{L}^{-1}\right)$. EtP was also shown to be degraded efficiently at low $\mathrm{O}_{3}$ doses $\left(\left[\mathrm{O}_{3}\right]_{0}=0.072-0.36 \mathrm{mg} \mathrm{L}^{-1}\right)$ [29].

Among the tested oxidant doses, $0.3 \mathrm{mg} \mathrm{L}^{-1}$ was chosen as the optimum one and used in further experiments, as this concentration was found to be able to ensure both rapid and complete depletion of the examined substrates, and also can result in lower operational cost.

\subsubsection{Degradation kinetics and determination of $R_{c t}$}

The experimental data acquired in the initial reaction phase under the various $\mathrm{O}_{3}$ doses applied, were well fitted in the pseudofirst-order kinetic model $\left(R^{2}>0.99\right)$. The apparent rate constant $k_{a p p}$ $\left(\mathrm{min}^{-1}\right)$ was significantly increased with increasing the oxidant concentration from 0.1 to $0.5 \mathrm{mg} \mathrm{L}^{-1}$. In the case of ERY, an increase in $k_{\text {app }}$ from $0.245 \mathrm{~min}^{-1}$ to $1.21 \mathrm{~min}^{-1}$ was observed when $\mathrm{O}_{3}$ dose increased from 0.1 to $0.5 \mathrm{mg} \mathrm{L}^{-1}$, whereas $k_{\text {app/EtP }}$ were found to be slightly higher compared to those of ERY.

One critical parameter that determines the oxidation potential of an ozonation system with regard to the degradation of a substrate $(S)$ is the contribution of both $\mathrm{O}_{3}$ - and $\mathrm{HO}^{\bullet}$-driven pathways. The partial contribution of both mechanisms can be accurately estimated by the time-integrated concentration of $\mathrm{O}_{3}$ and $\mathrm{HO}^{\bullet}$ (i.e. $\int_{0}^{t}\left[\mathrm{O}_{3}\right] d t ; \int_{0}^{t}\left[\mathrm{HO}^{\bullet}\right] d t$ ), representing $\mathrm{O}_{3}$ and $\mathrm{HO} \bullet$ exposure [24]. The relative importance of $\mathrm{O}_{3}$ - vs. $\mathrm{HO}^{\bullet}$-based oxidation reactions can be quantified with $R_{c t}$, which corresponds to the ratio of $\mathrm{HO}^{\bullet}$ - and $\mathrm{O}_{3}$-exposure [25]. Whilst, the concentration of $\mathrm{O}_{3}$ in a given aqueous matrix under particular reaction conditions is relatively straightforward to measure (i.e. indigo reagent), the major challenge of this task, lies in the difficulty in directly measuring the $\mathrm{HO}^{\bullet}$ concentration. Within this context, $\mathrm{HO}^{\bullet}$ concentration in the ozonated samples was indirectly determined using the competition kinetics approach, which is based on the monitoring of the depletion of an $\mathrm{O}_{3}$-resistant probe compound (e.g. $p$ CBA). $p$ CBA reacts readily with $\mathrm{HO}^{\bullet}\left(k_{\mathrm{HO}} / p C B A=5 \times 10^{9} \mathrm{M}^{-1} \mathrm{~s}^{-1}\right)$ and exhibits negligible reactivity to $\mathrm{O}_{3}\left(k_{\mathrm{O}_{3} / p C B A} \leq 1 M^{-1} s^{-1}\right)$ [25] (Eq. (1)).

$-\ln \frac{[p C B A]}{[p C B A]_{0}}=k_{H O^{*} / p C B A} \int_{0}^{t}\left[H O^{\circ}\right] d t=k_{H O^{*} / p C B A} R_{c t} \int_{0}^{t}\left[O_{3}\right] d t$

$R_{c t}$ can be calculated from the slope of the linear plot $-\ln \frac{[p C B A]}{[p C B A]_{0}}=$ $f\left(\int_{0}^{t}\left[\mathrm{O}_{3}\right] d t\right)$ using the experimental data of $p$ CBA concentration and $\mathrm{O}_{3}$ exposure (Fig. 2). The latter is calculated by integrating the area under the $\mathrm{O}_{3}$ depletion curve in an exponential plot of $\mathrm{O}_{3}$ concentration as a function of reaction time. $R_{c t}$ was found to be $1.9 \times 10^{-8}$ indicating that for the given wastewater matrix at the inherent $\mathrm{pH}, \mathrm{O}_{3}$ exposure is $10^{8}$ times greater than the total $\mathrm{HO}{ }^{\bullet}$ exposure. Thus, for an instantaneous concentration of $\mathrm{O}_{3}$ of $6.25 \mu \mathrm{M}$, the steady-state concentration of $\mathrm{HO}^{\bullet}$ is in the order of $10^{-14} \mathrm{M}$.

\subsubsection{Effect of solution $\mathrm{pH}$ on the degradation of ERY and EtP}

ERY and EtP degradation was considerably hindered under acidic conditions ( $\mathrm{pH} 3$ and 5), while the inherent $\mathrm{pH}$ value of wastewater (i.e. $\mathrm{pH} 8$ ) led to an accelerated degradation rate of both substrates accompanied with their complete removal within 2 min of reaction (Fig. 3). The degradation of ERY and EtP was 19\% and $52 \%$ at $\mathrm{pH} 3$, respectively, whereas a slightly higher degradation occurred at pH 5 (ERY removal $=25 \%$; EtP removal $=60 \%)$. Also, as exemplified in the inset graphs of Fig. 3, ERY and EtP degradation was kinetically affected, as $k_{a p p}$ was raised with increasing solution $\mathrm{pH}$ to 8 . 


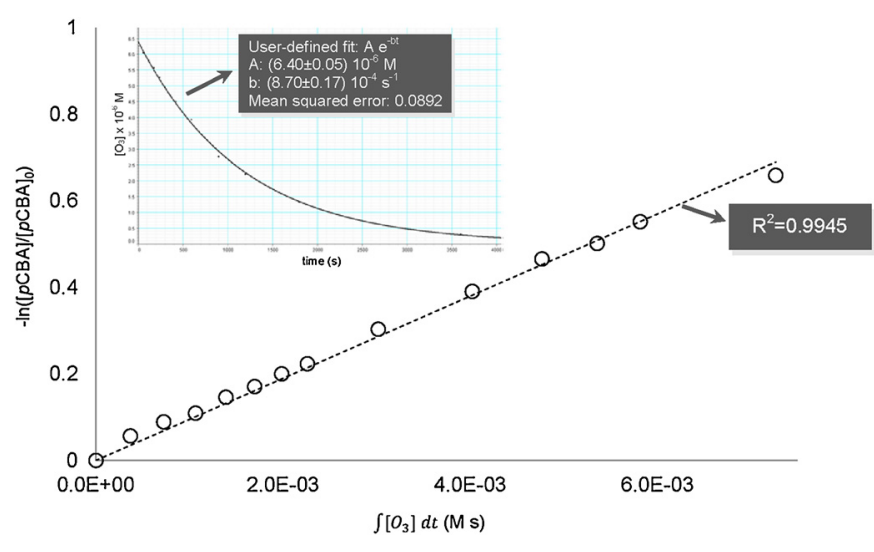

Fig. 2. Logarithmic decay of the concentration of $p C B A$ as a function of the integral $\mathrm{O}_{3}$ exposure. Inset graph depicts the depletion of $\mathrm{O}_{3}$ as a function of reaction time. Experimental conditions: $[p C B A]_{0}=0.5 \mu \mathrm{M} ;\left[\mathrm{O}_{3}\right]_{0}=6.2510^{-6} \mathrm{M} ; \mathrm{T}=25 \pm 2{ }^{\circ} \mathrm{C}$.

The rate of $\mathrm{O}_{3}$ decomposition increases with increasing solution $\mathrm{pH}$ (up to mild alkaline $\mathrm{pH}$ ) since $\mathrm{OH}^{-}$catalyse the decay of $\mathrm{O}_{3}$ yielding $\mathrm{HO}^{\bullet}$, which have a higher redox potential and a less-selective reactivity to a variety of organic compounds than molecular $\mathrm{O}_{3}$ [39]. Thus, it is expected and also confirmed by previous studies $[40,41]$ that the degradation of organic compounds being refractory to $\mathrm{O}_{3}$ attack, proceeds with appreciably higher rates at neutral or alkaline conditions. The inefficient degradation of ERY and EtP at $\mathrm{pH}$ 3 and 5 may be attributed to the fact that only molecular $\mathrm{O}_{3}$ is reacting directly with the compounds and the amount of $\mathrm{HO}^{\bullet}$ is scarce [37]. ERY and EtP undergo a higher degree of protonation in acidic medium and protonated molecules are known to react slowly with molecular $\mathrm{O}_{3}[42,43]$. A higher reactivity of EtP towards $\mathrm{O}_{3}$ compared to ERY under acidic conditions was also observed, presumably due to the activation of its electron-rich phenol moiety towards electrophilic attack as a result of the enhanced electrondonating character of $\mathrm{O}^{-}$relative to $\mathrm{OH}$ [24]. On the other hand, ERY was shown to be $\mathrm{O}_{3}$-recalcitrant as lower degradation of the antibiotic compared to EtP occurred under acidic conditions, reflecting its saturated-rich structure, which $\mathrm{O}_{3}$ would not preferentially attack [36].

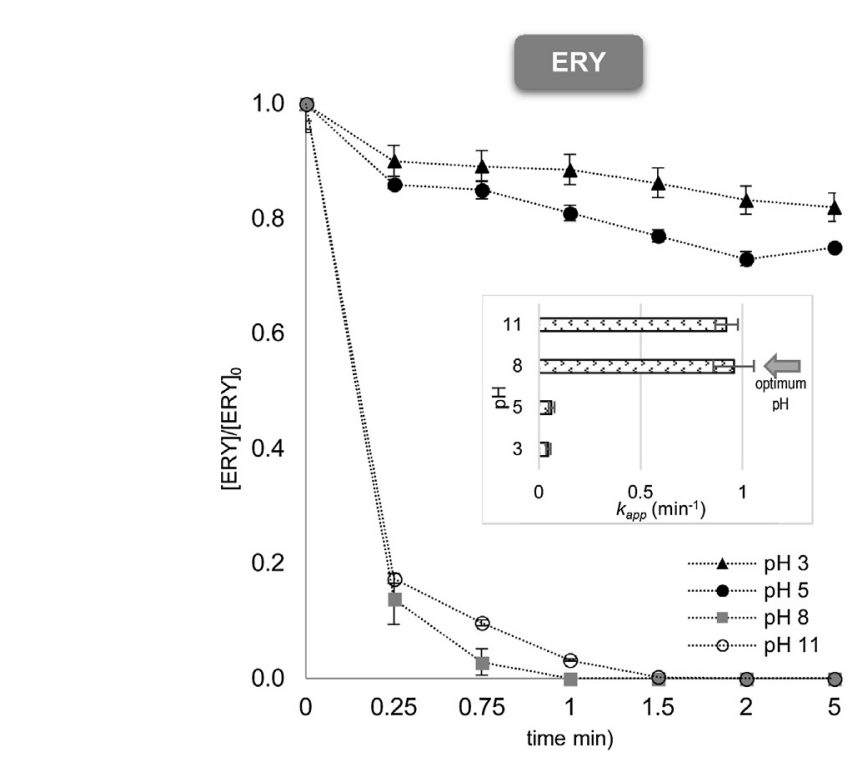

ERY and EtP degradation exhibited accelerated degradation rates at higher $\mathrm{pH}$ values compared to $\mathrm{pH} 3$ and 5 , where $\mathrm{HO}^{\bullet}$ concentration had become more significant. The degradation of ERY at $\mathrm{pH} 8$ and 11 exhibited similar pattern with $k_{\text {app }}$ being slightly lower at $\mathrm{pH} 11$, possibly due to the $\mathrm{HO}^{\bullet}$ consumption by carbonate species, which are generated at elevated $\mathrm{pH}$ values [24]. Therefore, these results do reveal that $\mathrm{HO}^{\bullet}$-mediated pathway is the predominant mechanism governing ERY transformation and are in agreement with the study of Lin et al. [28]. Contrarily, an inhibitory effect in EtP degradation was pronounced at $\mathrm{pH} 11$ $\left(\mathrm{EtP}_{\text {removal }}=50-60 \%, k_{\text {app }}=0.44 \mathrm{~min}^{-1}\right)$, indicating that the reaction of EtP with $\mathrm{O}_{3}$ is $\mathrm{pH}$-dependent. It is obvious that more research is needed for interpretation of the aforementioned behaviour.

Interestingly, the above findings suggested that both radical and non-radical pathways can contribute to the degradation of EtP, whereas this phenomenon did not appear to apply in the case of ERY. In order to corroborate the previous hypothesis, quenching experiments were carried out in the presence of $\mathrm{t}-\mathrm{BuOH}$ at the inherent $\mathrm{pH}$ (data not shown). The addition of $t-\mathrm{BuOH}$ disfavoured ERY degradation (merely reaching $10 \%$ ), while EtP was removed by $45 \%$ indicating the susceptibility of the latter to $\mathrm{O}_{3}$ attack. Of course, $\mathrm{O}_{3}$ reactivity with EtP was lower compared to the radical one, as shown in runs carried out under similar operating conditions in the absence of the $\mathrm{HO}^{\bullet}$ scavengers.

\subsubsection{Ozonation of ERY and EtP in different aqueous matrices}

In further experiments, the degradation of the target substrates in aqueous matrices of different composition (i.e. ultrapure water [UPW], bottled water [BW], synthetic humic acid solution [HA, $10 \mathrm{mg} \mathrm{L}^{-1}$ ] and secondary treated wastewater effluents [WW]) was investigated under the optimum $\mathrm{O}_{3}$ concentration (Fig. 4). The physicochemical characteristics of an aqueous matrix can affect $\mathrm{O}_{3}$ decomposition and consequently the formation of $\mathrm{HO} \bullet[35]$. As expected, the degradation of both substrates proceeded with higher rates in UPW in relation to BW, since the composition of the latter is enriched with carbonate species which inhibit $\mathrm{O}_{3}$ decay to $\mathrm{HO}^{\bullet}$ hence promoting the ozonation through the direct pathway [44]. The lowest contribution of $\mathrm{HO}^{\bullet}$ to ERY and EtP degradation in BW compared to UPW is also reflected to the $k_{\text {app }}$ values (inset graphs of Fig. 4). Moreover, as a consequence of the $\mathrm{dE}_{\mathrm{f}} \mathrm{OM}$ in $\mathrm{WW}$, lower degradation rates compared to UPW and BW were recorded,

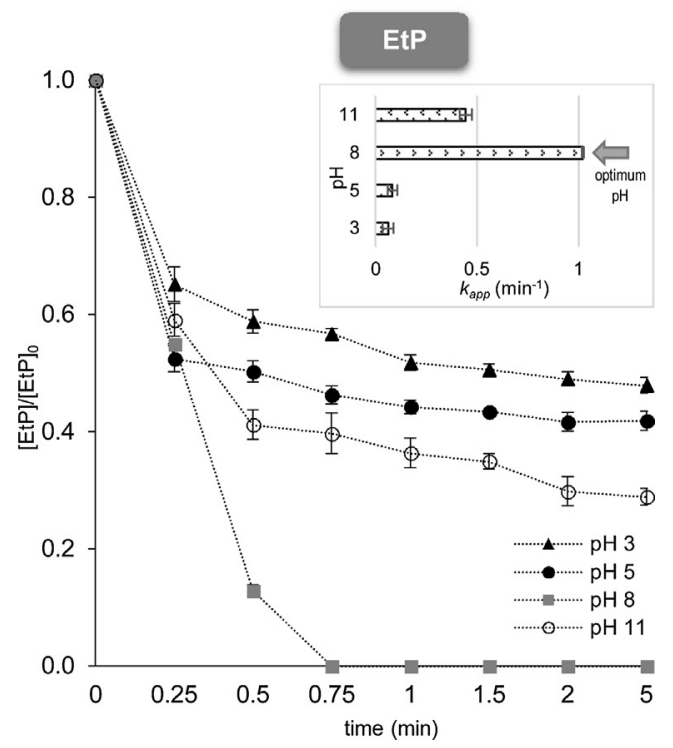

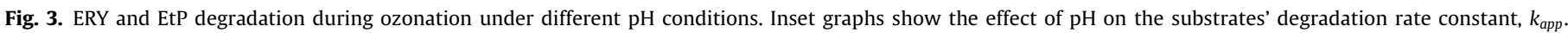
Experimental conditions: $[S]_{0}=100 \mu \mathrm{g} \mathrm{L}^{-1} ;\left[\mathrm{O}_{3}\right]_{0}=0.3 \mathrm{mg} \mathrm{L}^{-1} ; \mathrm{T}=25 \pm 2{ }^{\circ} \mathrm{C}$. 

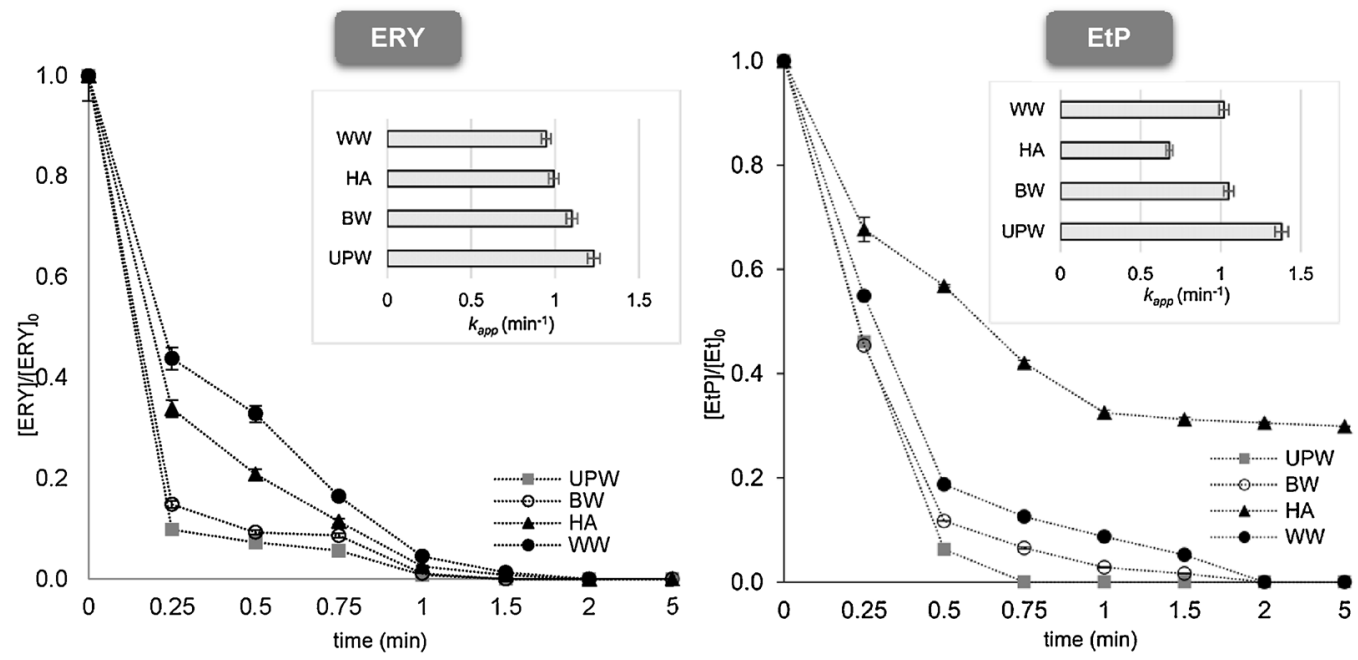

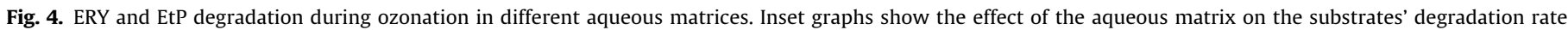
constant, $k_{\text {app }}$. Experimental conditions: $[S]_{0}=100 \mu \mathrm{g} \mathrm{L}^{-1} ;\left[\mathrm{O}_{3}\right]_{0}=0.3 \mathrm{mg} \mathrm{L}^{-1} ; \mathrm{pH} 8 ; \mathrm{T}=25 \pm 2{ }^{\circ} \mathrm{C}$.

as the reaction of $\mathrm{HO}^{\bullet}$ with the substrates was suppressed. Benitez et al. [45] observed that the removal of metoprolol, naproxen, amoxicillin, and phenacetin was higher in surface water compared to groundwater, while a significantly lower removal of these compounds was obtained in the case of wastewater effluents.

Interestingly, experimental runs carried out using HA solution showed that the degradation rate of EtP was lower compared to that observed in WW $\left(k_{\text {app } / H A}=0.68 \mathrm{~min}^{-1}<k_{\text {app } / W W}=1.02 \mathrm{~min}^{-1}\right)$, whereas a reverse behaviour occurred in the case of ERY $\left(k_{a p p / \mathrm{HA}}=0.992 \mathrm{~min}^{-1}>k_{\text {app }} / \mathrm{WW}=0.937 \mathrm{~min}^{-1}\right)$. Here it is noted that the DOC of $\mathrm{HA}$ and WW was approximately the same $\left(\mathrm{DOC}_{\mathrm{WW}}=\mathrm{DOC}_{\mathrm{HA}} \approx 8 \mathrm{mg} \mathrm{L}^{-1}\right)$. Thus, it can be inferred that not only the concentration of organic matter (quantified as DOC) but also its origin might determine the rate of $\mathrm{O}_{3}$ decomposition and consequently the overall process efficiency. However, further research is needed to determine the complex mechanisms responsible for these observations and to withdraw safe conclusions.

\subsection{Bromate formation during ozonation}

A major challenge associated with the ozonation of bromidecontaining wastewater $\left(\mathrm{Br}^{-}>0.1 \mathrm{mg} \mathrm{L}^{-1}\right)$ is the inevitable formation of bromate $\left(\mathrm{BrO}_{3}{ }^{-}\right)$, which is generated through a sequence of oxidation reactions involving both $\mathrm{O}_{3}$ and $\mathrm{HO} \bullet$ [46]. The formation of $\mathrm{BrO}_{3}{ }^{-}$during wastewater ozonation has so far received much less attention compared to drinking water [24,35]. EU and USEPA have already established the value of $10 \mu \mathrm{g} \mathrm{L}^{-1}$ as the maximum $\mathrm{BrO}_{3}{ }^{-}$level in drinking water [47].

Fig. 5 depicts the formation profile of $\mathrm{BrO}_{3}{ }^{-}$at $\mathrm{pH} 5$ and 8 as a function of $\mathrm{O}_{3}$ dose. It was observed that the $\mathrm{O}_{3}$ dose, under both $\mathrm{pH}$ conditions, while maintaining a constant contact time of $30 \mathrm{~min}$, strongly affects the formation of $\mathrm{BrO}_{3}{ }^{-}$, the latter being pronounced at higher oxidant doses (i.e. $\left[\mathrm{O}_{3}\right]_{0}=2.5 \mathrm{mg} \mathrm{L}^{-1}$ ). At $\mathrm{pH}$ 5 , lower formation of $\mathrm{BrO}_{3}{ }^{-}$was observed compared to that at the inherent $\mathrm{pH}$. At $\mathrm{pH} 8$, ozonation with $2.5 \mathrm{mg} \mathrm{L}^{-1}$ of $\mathrm{O}_{3}$ resulted in the formation of $31.1 \mu \mathrm{g} \mathrm{L}^{-1}$ of $\mathrm{BrO}_{3}{ }^{-}$, while at $\mathrm{pH} 5$ the $\mathrm{BrO}_{3}{ }^{-}$ concentration was $24.5 \mu \mathrm{g} \mathrm{L}^{-1}$. At the lowest $\mathrm{O}_{3}$ dose, the difference of $\mathrm{BrO}_{3}{ }^{-}$level in the reaction solution at both $\mathrm{pH} 5$ and 8 was less pronounced and $\mathrm{BrO}_{3}{ }^{-}$concentration was less than $10 \mu \mathrm{g} \mathrm{L}^{-1}$ $\left(\left[\mathrm{BrO}_{3}{ }^{-}\right]_{\mathrm{pH} 5}=5.5 \mu \mathrm{g} \mathrm{L}^{-1} ;\left[\mathrm{BrO}_{3}{ }^{-}\right]_{\mathrm{pH} 8}=6.2 \mu \mathrm{g} \mathrm{L}^{-1}\right)$. Buffle et al. [48] reported that $\mathrm{OBr}^{-}$is two orders of magnitude lower at $\mathrm{pH} 6$ compared to $\mathrm{pH} 8$, while the difference in $\mathrm{O}_{3}$ and $\mathrm{HO}^{\bullet}$ exposure under both $\mathrm{pH}$ conditions may also contribute towards $\mathrm{BrO}_{3}{ }^{-}$reduction. For the experimental conditions applied herein and taking into account the $R_{c t}$ value, it can be assumed that the contribution of molecular $\mathrm{O}_{3}$ to the formation of $\mathrm{BrO}_{3}{ }^{-}$was more significant than that of $\mathrm{HO}^{\bullet}$. Nonetheless, due to the complexity of the $\mathrm{BrO}_{3}{ }^{-}$formation mechanism, it cannot be expected that $\mathrm{BrO}_{3}{ }^{-}$formation is directly proportional to $R_{c t}$ and, thus no concrete conclusions can be withdrawn.

In general, controlling the $\mathrm{BrO}_{3}{ }^{-}$formation dictates lowering the oxidant concentration and the wastewater $\mathrm{pH}$ as possible, although the latter scenario cannot be considered as an economical solution for real-word applications. The findings of this study clearly revealed that an $\mathrm{O}_{3}$ dose lower than $0.5 \mathrm{mg} \mathrm{L}^{-1}$ should be kept at the wastewater inherent $\mathrm{pH}$, if $\mathrm{BrO}_{3}{ }^{-}$concentration needs to be lower than the maximum contaminant level of $10 \mu \mathrm{g} \mathrm{L}^{-1}$.

\subsection{Identification of the major transformation products (TPS) of ERY and EtP}

The oxidation of ERY and EtP during ozonation ( $\mathrm{pH} 8$ ), gave rise to a number of distinct TPs characterized by different $\mathrm{m} / \mathrm{z}$ ratios and molecular structures. The structural assignment of the TPs was deduced on the basis of the UPLC-MS ${ }^{2}$ data and the prior knowledge on the degradation mechanisms of ERY [31,49,50] and other parabens [28,29,51-53] during oxidation and biodegradation experiments. The postulated chemical structures of the main TPs elucidated during the oxidation of ERY and EtP by the ozonation process are depicted in Schemes 1 a and 2 , respectively. Overall, the screening of the ozonated samples led to the identification of five TPs during the oxidation of ERY (TP1-TP5), while fifteen TPS were detected in the case of $\operatorname{EtP}\left(\boldsymbol{T P 1}^{*}-\mathbf{T P 1 5}^{*}\right)$.

\subsubsection{TPS of ERY}

The degradation of ERY during ozonation was accompanied by the formation of five TPs preserving the macrocyclic lactone ring of its molecule. The major structural alterations seem to take place in the cladinose moiety, as well as in some positions of the lactone ring.

TP1 $(m / z$ 750) resulted from the concomitant demethylation and hydroxylation at the $\mathrm{C}-2$ position of the lactone ring of the molecule. Further dehydrogenation of TP1 yielded two positional isomers with $m / z$ 748, TP2(A) and TP2(B), leading to the formation of a carbonyl group $(-\mathrm{C}=\mathrm{O})$ at $\mathrm{C}-2$ position and cyclization of the lactone ring with cladinose, respectively. A third isobaric isomer (TP2(C)), was also identified, deriving presumably from the spontaneous dehydrogenation and methylation of the $-\mathrm{OH}$ at position 
a

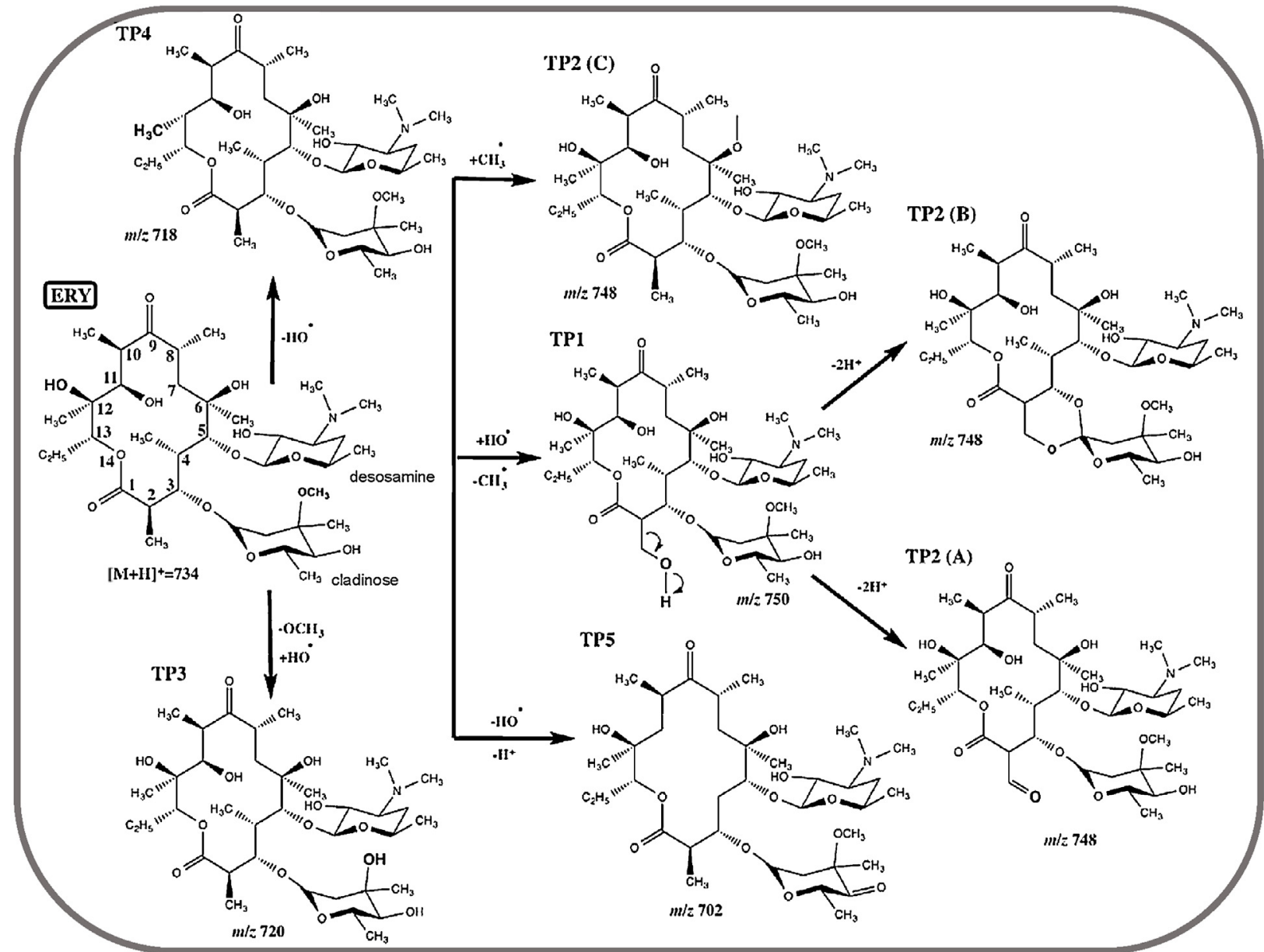

b

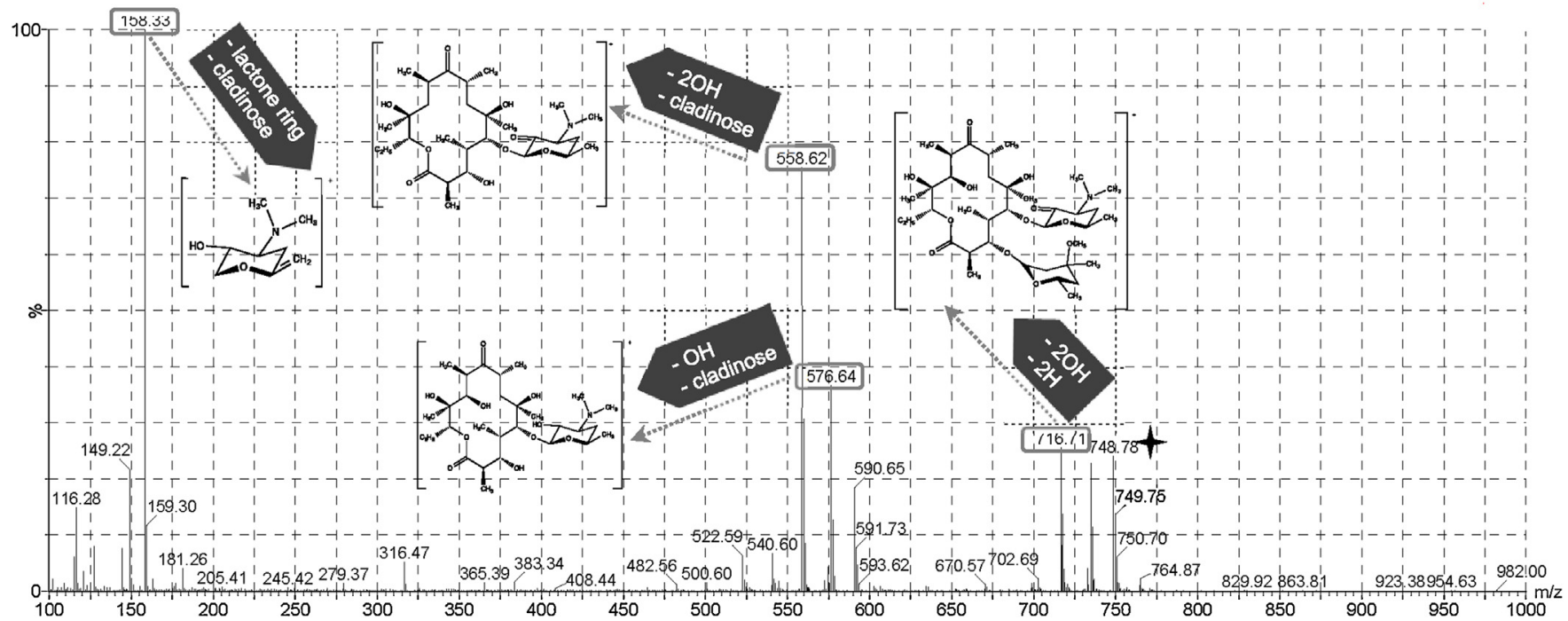

Scheme 1. (a) The proposed transformation pathway of ERY degradation during ozonation. (b) Product ion MS ${ }^{2}$ spectrum of TP2.

C-6 of the lactone ring of ERY. The MS² fragmentation pattern of TP2 is shown in Scheme $1 \mathrm{~b}$.

The formation of TP3 $(\mathrm{m} / \mathrm{z} 720)$ may be attributed to the loss of the methoxy group $\left(-\mathrm{OCH}_{3}\right)$ of cladinose followed by hydroxylation at the same position, while the formation of $\mathbf{T P 4}(\mathrm{m} / z$ 718) corresponds to the loss of a $\mathrm{HO}^{\bullet}$ at position $\mathrm{C}-12$ of the lactone ring.
Finally, dehydroxylation at position C-11 and dehydrogenation of the cladinose moiety of ERY, led to the formation of TP5 $(\mathrm{m} / z$ 702).

\subsubsection{TPS of EtP}

The structure of the TPs identified in this study shows preservation of the aromatic ring of the EtP molecule, while the structural alterations have taken place at the ethyl ester chain due to $\mathrm{HO}^{\bullet}$ 


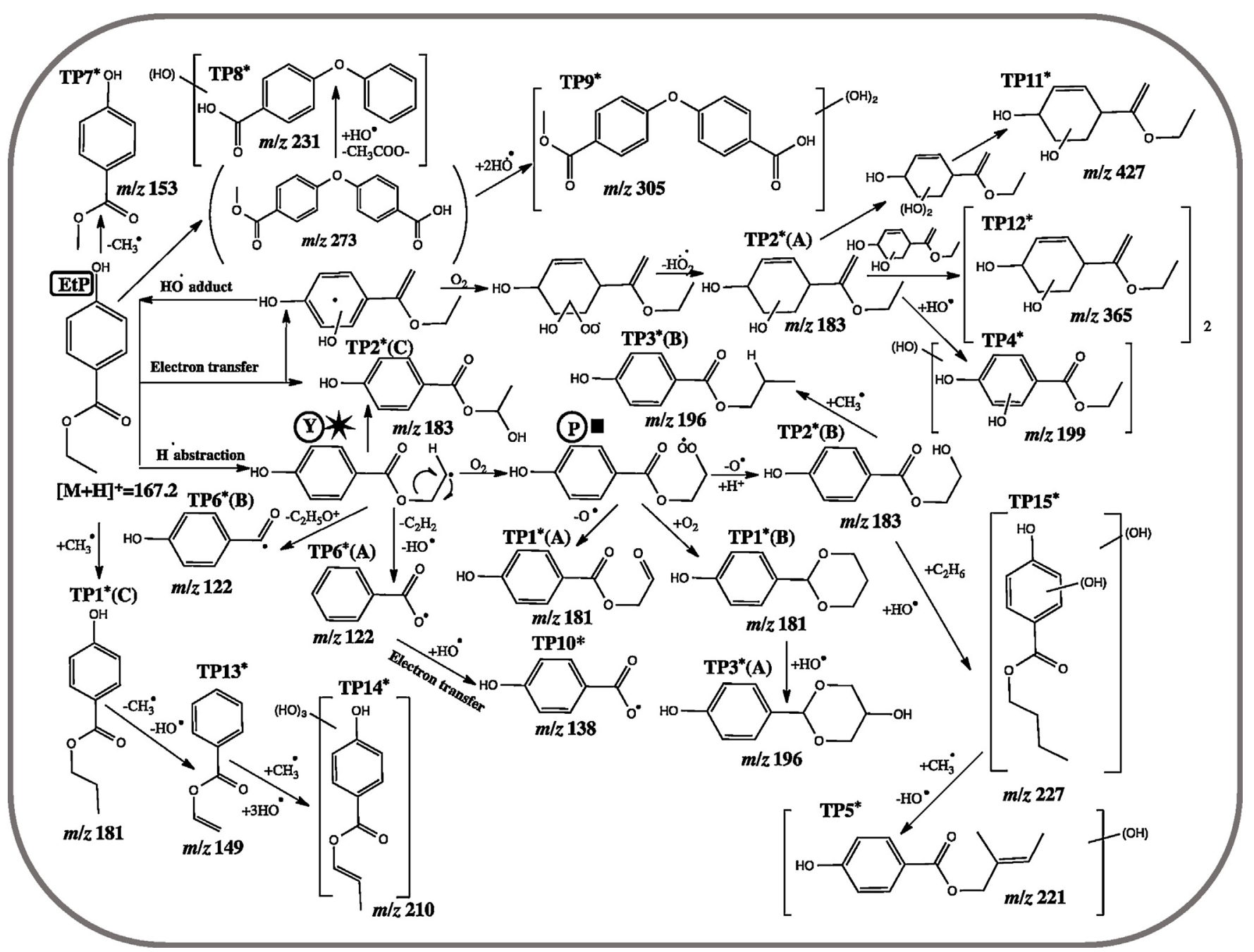

Scheme 2. The proposed transformation pathway of EtP degradation during ozonation.

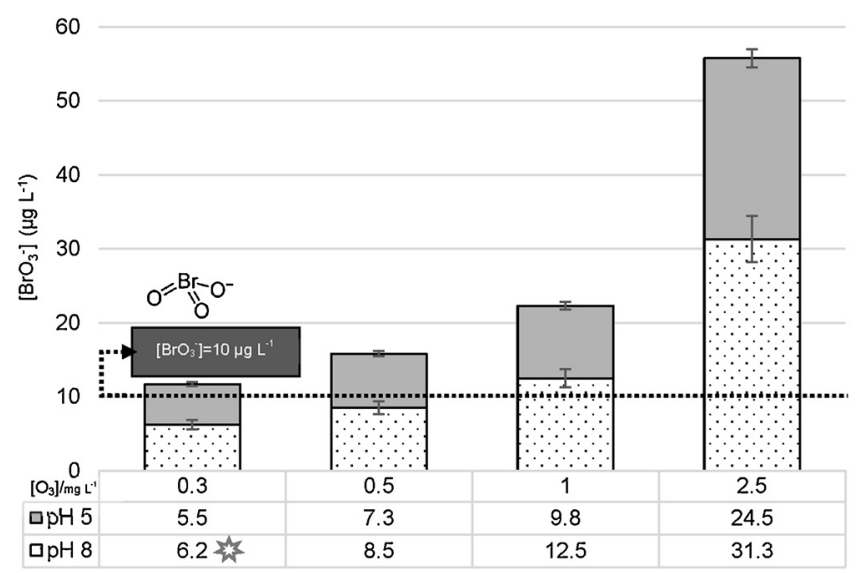

Fig. 5. Formation of $\mathrm{BrO}_{3}{ }^{-}$as a function of $\mathrm{O}_{3}$ dose and $\mathrm{pH}$.

attack. The TPs identified indicate that $\mathrm{HO}^{\bullet}$ are the predominant oxidative species initiating the attack to EtP, mainly through hydrogen abstraction and $\mathrm{HO}^{\bullet}$ adduct mechanisms.

Two isomers $\left(\right.$ TP2*$^{*}(\boldsymbol{B})$, TP2 $\left.^{*}(\boldsymbol{C}), m / z 183\right)$ appeared as soon as the ozonation process began which were produced via hydroxylation of the ethyl ester chain of EtP. Presumably, $\boldsymbol{T P 2}^{*}(\boldsymbol{B})$ arises through a sequence of reactions involving hydrogen abstraction yielding one carbon-centered radical intermediate ( $\boldsymbol{Y}$, marked with an asterisk), which in turn can react with dissolved $\mathrm{O}_{2}$ to produce a peroxy radical intermediate ( $\boldsymbol{P}$, marked with a square). The latter primarily produces a tetroxide, which can decompose into hydroxyl and carbonyl groups on the alkyl chain, producing $\operatorname{TP2}^{*}(\boldsymbol{B})$ and $\boldsymbol{T P 1}^{*}(\boldsymbol{A})$ $(\mathrm{m} / \mathrm{z}$ 181).P was also reported by Fang et al. [51] during the transformation of propylparaben by $\mathrm{TiO}_{2}$-photocatalysis. TP1*(B) $(m / z 181)$ was formed upon addition of $\mathrm{O}_{2}$ to product $\boldsymbol{P}$, provoking the cyclization of the ethyl ester chain of EtP. The addition of one $-\mathrm{OH}$ onto the 1,3-dioxane ring of $\mathbf{T P 1}{ }^{*}(\boldsymbol{B})$ resulted in the formation of TP3* $(\boldsymbol{A})$ $\left(\mathrm{m} / \mathrm{z}\right.$ 196), while an addition of $-\mathrm{CH}_{3}$ methyl group onto the ethyl ester chain of $\boldsymbol{T P 2}^{*}(\boldsymbol{B})$ led to the generation of $\mathbf{T P} \mathbf{3}^{*}(\boldsymbol{B})$. The formation of TP3*(B) was also observed during the photo-sonochemical degradation of butyl-paraben [54].

In parallel to hydrogen abstraction, direct hydroxylation of $\boldsymbol{Y}$ occurred leading to the formation of $\boldsymbol{T P 2}^{*}(\boldsymbol{C})$. $\boldsymbol{Y}$ was also converted into two new isomers with $m / z 122 ;$ TP6 $^{*}(\boldsymbol{A})$ through the abstraction of $-\mathrm{C}_{2} \mathrm{H}_{2}$ and addition of $\mathrm{HO}^{*}$, and $\mathbf{T P 6}^{*}(\boldsymbol{B})$ due to the elimination of $-\mathrm{C}_{2} \mathrm{H}_{5} \mathrm{O}^{+}$.

TP2 $^{*}(\boldsymbol{A})$ was generated though an $\mathrm{HO}^{\bullet}$ adduct mechanism, which in turn contributed to the formation of TP11* $^{*}(\mathrm{~m} / z$ 427). TP12* $^{*}(m / z$ 365) and TP4* $(m / z$ 199) were generated after dimerization and hydroxylation of $\mathbf{T P 2}^{*}(\boldsymbol{A})$, respectively.

TP15* ( $m / z$ 227) was derived from the hydroxylation of the EtP aromatic ring followed by the addition of an ethyl group on the ethyl moiety, which upon further methylation and dehydroxylation yielded TP5* $(m / z$ 221). The formation of TP8* $(m / z 231)$ 

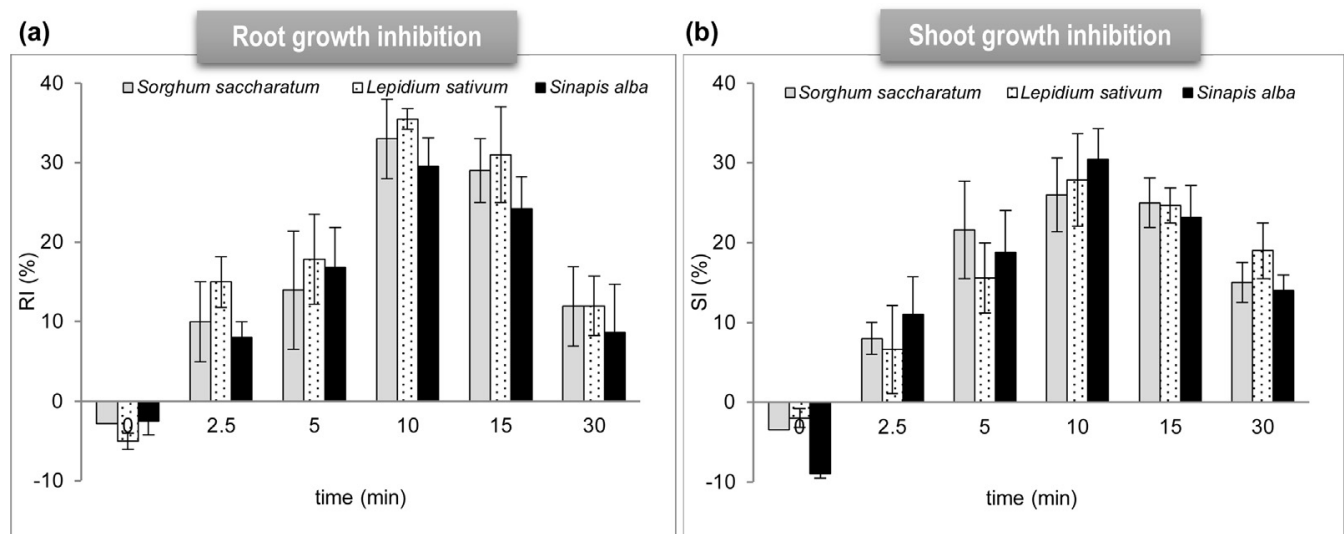

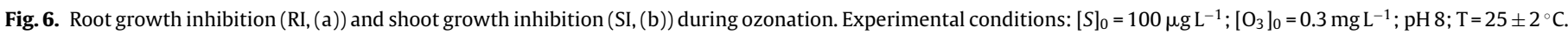

corresponds to the breakdown of the ethyl ester chain of the intermediate compound $(\mathrm{m} / \mathrm{z} 2 \mathrm{273})$, through the loss of an acetate group $\left(-\mathrm{CH}_{3} \mathrm{COO}-\right)$ and further addition of $-\mathrm{OH}$. Further addition of two $-\mathrm{OH}$ on the aforementioned intermediate resulted in the formation of TP9* $(m / z$ 305).

Direct methylation of the ethyl ester chain has also been observed to occur and this was evidenced by the generation of propylparaben, corresponding to $\boldsymbol{T P 1}^{*}(\boldsymbol{C})$. Demethylation of the ethyl ester chain of EtP produced methylparaben $(\boldsymbol{T P 7} *, m / z 153)$. The elucidation route of the formation of TP13* $\left.^{*} \mathrm{~m} / \mathrm{z} 149\right)$ can be attributed to the simultaneous abstraction of $-\mathrm{CH}_{3}$ and $-\mathrm{OH}$ from the aliphatic chain of $\boldsymbol{T P 1}^{*}(\boldsymbol{C})$. TP14* $(\mathrm{m} / z 210)$ was detected in the treated samples as a result of the hydroxylation of the aromatic ring accompanied with an addition of $-\mathrm{CH}_{3}$ on the ethynyl moiety of TP13*.

The molecular formula postulated for $\boldsymbol{T P 1 0}^{*}(\mathrm{~m} / \mathrm{z} 138)$ can been assigned to $p$-hydroxybenzoic acid, whose formation can be ascribed to the loss of $-\mathrm{C}_{3} \mathrm{H}_{7}$. TP10* was previously reported in other studies [51,52].

\subsection{Mineralization and phytotoxicity assessment}

The DOC of the reaction solution (corresponding to the inherent DOC of the wastewater that includes the low concentration of the spiked substrates and of their corresponding TPs) decreased gradually over the entire experimental duration ( $30 \mathrm{~min}$ ) and then levelled off. A significant improvement in the mineralization level achieved was experienced when increasing the $\mathrm{O}_{3}$ dose from $0.1 \mathrm{mg} \mathrm{L}^{-1}\left(\mathrm{DOC}_{\text {removal }}=23-25 \%\right.$ ) to $0.5 \mathrm{mg} \mathrm{L}^{-1}\left(\mathrm{DOC}_{\text {removal }}=60-66 \%\right)$. At $\left[\mathrm{O}_{3}\right]=0.3 . \mathrm{mg} \mathrm{L}^{-1}$, the residual DOC recorded at the end of treatment was between $5.6-7.7 \mathrm{mg} \mathrm{L}^{-1}$. The relatively low yield of DOC removal compared to the substrates' depletion clearly points out the formation of recalcitrant organic intermediates deriving from the oxidation of the $\mathrm{dE}_{\mathrm{f}} \mathrm{OM}$, as complete mineralization was not attained in any case.

In further experiments, the potential phytotoxicity of $\mathrm{dE}_{\mathrm{f}} \mathrm{OM}$ oxidation products towards three plant species was evaluated. Two set of experimental runs (i.e. in the absence/presence of ERY and EtP in the reaction solution) were performed in order to exclude the contribution of the TPs resulted from the oxidation of the parent compounds. The results of both experimental series clearly indicated that the ozonated samples induced the same variation in the phytotoxicity profile, implying thus that the seed germination and the growth of roots and shoots were neither affected by the presence of the parent compounds nor by their TPs (data not shown). Therefore, the inhibition effects observed can be ascribed to the $\mathrm{dE}_{\mathrm{f}} \mathrm{OM}$ and its associated oxidation products.
The samples did not exert any adverse influence on the germination of the tested plant species. On the other hand, the variety of the oxidation products generated from the transformation of $\mathrm{dE}_{\mathrm{f}} \mathrm{OM}$ during ozonation resulted in the augmentation of phytotoxic response (Fig. 6). Root and shoot inhibition (RI and SI, respectively) reached their highest values when the seeds were exposed to the samples taken after 10 min of treatment, indicating that $\mathrm{dE}_{\mathrm{f}} \mathrm{OM}$ oxidation products were potentially more toxic than the original matrix. As ozonation progressed (15 min), RI and SI remained at the same level, indicating that the oxidation products formed were still present in the reaction solution and/or that new toxic oxidation products were arisen. After $30 \mathrm{~min}$ of treatment, RI and SI decreased to $9-12 \%$ and $14-19 \%$, respectively.

According to the authors' knowledge, there is no available literature dealing with the phytotoxic effects of the $\mathrm{dE}_{\mathrm{f}} \mathrm{OM}$ oxidation products formed during ozonation. Nevertheless, results obtained from other studies are rather conflicting, as the variety of toxicological tests applied so far have shown that ozonation may either increase or decrease the biological effects. For example, Stalter et al. [55] observed that wastewater subjected to ozonation enhanced toxicity towards Lytechinus variegatus, while a significantly increased genotoxicity was also recorded. In another study of Stalter et al. [56], the fish early life stage toxicity test revealed a developmental retardation of Oncorhynchus mykiss after its exposure to ozonated wastewater. Ozonation was shown to enhance mutagenicity of wastewater possibly due to the formation of various intermediates [44]. Inconsistent findings on the acute biological effects of ozonated wastewater have been reported by Altmann et al. [57], showing that the tested organisms were not adversely affected by the presence of $\mathrm{dE}_{\mathrm{f}} \mathrm{OM}$ oxidation products.

The above findings clearly indicate that ozonation of $\mathrm{dE}_{\mathrm{f}} \mathrm{OM}$ comes with the risk of producing oxidation products with potential phytotoxic effects. The complex structure of $\mathrm{dE}_{\mathrm{f}} \mathrm{OM}$ however, renders difficult the identification of the specific oxidation products that may be responsible for the observed phytotoxic effects. Ozonation of wastewater which finds an increasing application acceptance during the last years, should be evaluated with respect to its capacity not only to remove microcontaminants, but also biological effects, especially when the treated flows are intended for reuse applications.

\subsection{E. coli disinfection potential of ozonation}

E. coli constitute the most important indicator of faecal contamination and antibiotic resistance in wastewater and, thus they were chosen as ideal candidates for evaluating the disinfection capacity of the ozonation process applied in this study. E. coli present originally in wastewater were evaluated for their resistance to both 


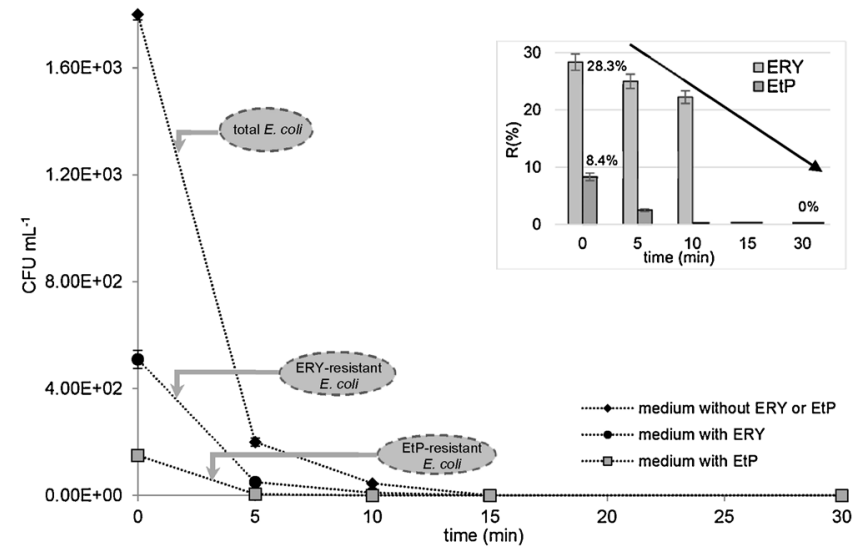

Fig. 7. Profile of total, ERY- and EtP-resistant E. coli during ozonation (expressed as $\mathrm{CFU} \mathrm{mL} \mathrm{m}^{-1}$ ). Inset graph illustrates the resistance percentage profile during ozonation. Experimental conditions: $[S]_{0}=100 \mu \mathrm{g} \mathrm{L}^{-1} ;\left[\mathrm{O}_{3}\right]_{0}=0.3 \mathrm{mg} \mathrm{L}^{-1} ; \mathrm{pH} 8$; $\mathrm{T}=25 \pm 2{ }^{\circ} \mathrm{C}$.

ERY and EtP, while in further experiments the feasibility of the ozonation process in removing ERY- and EtP-resistant bacteria was assessed. The average bacterial density of total cultivable and resis-

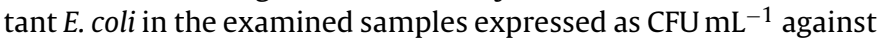
treatment time is shown in Fig. 7. The average inherent E. coli concentration in the wastewater samples was $1.8 \times 10^{3} \mathrm{CFU} \mathrm{mL}^{-1}$ and the bacterial population was completely inactivated within 15 min of ozonation. In accordance with these findings, Xu et al. [58] reported that $2 \mathrm{~min}$ of exposure were sufficient for inactivating E. coli during ozonation $\left(\left[\mathrm{O}_{3}\right]=10-40 \mathrm{mg} \mathrm{L}^{-1}\right)$. The concentrations of ERY- and EtP-resistant E. coli in the treated samples were much lower compared to their respective concentrations in the untreated effluent, while neither ERY- nor EtP-resistant E. coli were detected after $15 \mathrm{~min}$ of ozonation. Comparing the resistance percentage for the two compounds tested, it is clearly demonstrated that resistance to ERY was always much higher than that of EtP. Interestingly, all colonies harbouring resistance to ERY apparently survived ozonation better than EtP-resistant E. coli as they were still present in solution after $5 \mathrm{~min}$. The aforementioned statement however is very premature as it should be supported by strong evidence, e.g. additional runs with statistical validation.

According to the authors' knowledge, there are limited studies dealing with the removal of ARB by ozonation, while the lack of data on parabens, prevents reaching a definitive answer as to their role in selecting for bacterial resistance. Lüddeke et al. [59] observed that ozonation followed by filtration led to a decrease (0.8-1.1 log-units) in the percentage of antibiotic-resistant $E$. coli against selected antibiotics. The resistance of $E$. coli against ERY during wastewater ozonation was investigated by Luczkiewicz et al. [60], showing that the percentage of ERY-resistant isolates was lower after ozonation (a reduction of about 20.7\%). Also, ozonation was found to induce an oxidative damage on the plasmid DNA of multi-resistant $E$. coli and the damage increased with increasing oxidant doses [61]. The superiority of the ozonation process over sulfate radical-based oxidation process under UV-C irradiation in inactivating ERY-resistant $E$. coli has been also demonstrated in this study, as the bacteria were eliminated at longer time of the UV-C treatment (45 min) compared to ozonation [31].

One critical issue governing the application of $\mathrm{O}_{3}$-based processes is the formation of 'new' compounds (i.e. TPs) originating from the oxidation of antimicrobials present in wastewater (in this case ERY and EtP), which may exhibit their own antimicrobial effects. Although EtP was structurally modified, its TPs preserved its phenolic moiety. Considering the fact that the antimicrobial action of parabens is allocated to their phenolic moiety [62], one might speculate that these TPs maintain these antibacterial properties. In the case of ERY, all the TPs seem to possess its core structure, sustaining thus the hypothesis that these may exhibit the same antimicrobial activity with ERY. No data currently exist on the capacity of the TPs of antimicrobials to contribute to bacterial resistance and therefore this aspect remains a current open challenge especially when reference standards are not available. Here it is noted that a new project (H2020-MSCA-ITN-2015/675530) has recently initiated its activities that include among others evaluation of the potential of TPs of antibiotics to induce antibiotic resistance.

\section{Conclusions}

The findings of this study demonstrated that ozonation of wastewater operated at the inherent $\mathrm{pH}$ and at low $\mathrm{O}_{3}$ doses, constitutes a promising treatment technology for the elimination of antimicrobials (ERY and EtP), total E. coli, as well as E. coli harbouring resistance to ERY and EtP. The process efficiency in removing ERY and EtP increased with increasing oxidant dosage, while the degradation of both substrates was found to follow a pseudofirst-order kinetics. Combined information of degradation kinetics $\left(k_{a p p}\right)$ and contribution of $\mathrm{O}_{3}-$ and $\mathrm{HO}^{\bullet}$-driven mechanisms $\left(R_{c t}\right)$ allowed for the determination of the oxidation potential of the ozonation system for the specific wastewater used. The experimental results revealed that $\mathrm{pH}$ control is essential to the process optimization, indicating that the inherent $\mathrm{pH}$ favours the degradation of both substrates. ERY degradation seemed to be mainly driven by $\mathrm{HO}^{\bullet}$, whereas both $\mathrm{O}_{3}$ and $\mathrm{HO}^{\bullet}$-mediated pathways contribute to EtP degradation. The presence of inorganic and/or organic constituents in BW, HA and WW can inhibit the degradation of the target substrates. The findings of this study demonstrated that $\mathrm{BrO}_{3}{ }^{-}$concentration is lower than $10 \mu \mathrm{g} \mathrm{L}^{-1}$ when the applied $\mathrm{O}_{3}$ dose is maintained lower than $0.5 \mathrm{mg} \mathrm{L}^{-1}$. The transformation of ERY and EtP proceeded through the formation of a variety of TPs, whose molecular structure retained the core structure of the parent compounds. From the ecotoxicological perspective, main concerns related to wastewater ozonation revolve around the potential formation of persistent $\mathrm{dE}_{\mathrm{f}} \mathrm{OM}$ oxidation products, which have been shown to significantly affect root and shoot growth of the tested plant species. ERY-resistant E. coli seemed to be less susceptible to ozonation compared to EtP-resistant $E$. coli, while ozonation resulted in complete elimination of total $E$. coli and those carrying resistance to ERY and EtP individually.

\section{Disclaimer}

The content of this article is the author's responsibility and neither COST nor any person acting on its behalf is responsible for the use, which might be made of the information contained in it.

\section{Acknowledgements}

This work was carried out in the framework of the

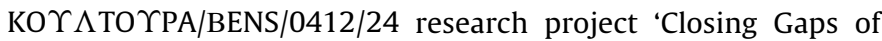
Knowledge with respect to Advanced Chemical Oxidation Processes for the Removal of Contaminants of Emerging Concern (GAPS)', implemented within the national framework program for research, technological development and innovation 'DESMH

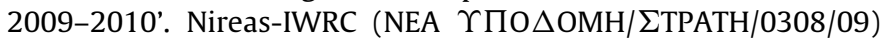
was co-financed by the Republic of Cyprus and the European Regional Development Fund through the Research Promotion Foundation of Cyprus. The authors would like to acknowledge the COST-European Cooperation in Science and Technology Action ES1403: New and emerging challenges and opportunities in 
wastewater reuse (NEREUS), for stimulating the work implemented in the manuscript.

\section{References}

[1] COM, 2012. A Blueprint to Safeguard Europe's Water Resources. http://eurlex.europa.eu/legal-content/EN/TXT/PDF/?uri=CELEX: 52012DC0673\&from $=$ EN

[2] I. Michael, L. Rizzo, C. McArdell, C. Manaia, C. Merlin, T. Schwartz, C. Dagot, D. Fatta-Kassinos, Urban wastewater treatment plants as hotspots for the release of antibiotics in the environment: a review, Water Res. 47 (2013) 957-995.

[3] D. Błędzka, J. Gromadzińska, W. Wąsowicz, Parabens. From environmental studies to human health, Environ. Int. 67 (2014) 27-42.

[4] W. Li, Y. Shi, L. Gao, J. Liu, Y. Cai, Occurrence, fate and risk assessment of parabens and their chlorinated derivatives in an advanced wastewater treatment plant, J. Hazard. Mater. 300 (2015) 29-38.

[5] T.U. Berendonk, C.M. Manaia, C. Merlin, D. Fatta-Kassinos, E. Cytryn, F. Walsh, H. Bürgmann, H. Sørum, M. Norström, M.N. Pons, N. Kreuzinger, P. Huovinen, S. Stefani, T. Schwartz, V. Kisand, F. Baquero, J.L. Martinez, Tackling antibiotic resistance: the environmental framework, Nat. Rev. Microbiol. 13 (2015) 310-317.

[6] D.I. Andersson, D. Hughes, Microbiological effects of sublethal levels of antibiotics, Nat. Rev. Microbiol. 12 (2014) 465-478.

[7] C.M. Manaia, G. Macedo, D. Fatta-Kassinos, O.C. Nunes, Antibiotic resistance in urban aquatic environments: can it be controlled? Appl. Microbiol. Biotechnol. 100 (2015) 1543-1557.

[8] SCENIHR (Scientific Committee on Emerging and Newly Identified Health Risks). Assessment of the Antibiotic Resistance Effects of Biocides. European Commission, 2009, http://ec.europa.eu/health/archive/ph_risk/committees/ 04_scenihr/docs/scenihr_o_021.pdf.

[9] K.K. Selvaraj, S. Sivakumar, S. Sampath, G. Shanmugam, U. Sundaresan, B.R. Ramaswamy, Paraben resistance in bacteria from sewage treatment plant effluents in India, Water Sci. Technol. 68 (2013) 2067-2073.

[10] EU, 2015/495. Commission implementing decision establishing a watch list of substances for Union-wide monitoring in the field of water policy pursuant to Directive 2008/105/EC of the European Parliament and of the Council, http:// eur-lex.europa.eu/legal-content/EN/TXT/PDF/?uri=CELEX: 32015D0495\&from=EN

[11] B.Y. Liu, X.P. Nie, W.Q. Liu, P. Snoeijs, C. Guan, M.T.K. Tsui, Toxic effects of erythromycin, ciprofloxacin and sulfamethoxazole on photosynthetic apparatus in Selenastrum capricornutum, Ecotoxicol. Environ. Saf. 74 (2011) 1027-1035.

[12] K. Ji, S. Kim, S. Han, J. Seo, S. Lee, Y. Park, K. Choi, Y.L. Kho, P.G. Kim, J. Park, K. Choi, Risk assessment of chlortetracycline, oxytetracycline, sulfamethazine, sulfathiazole, and erythromycin in aquatic environment: are the current environmental concentrations safe? Ecotoxicology 21 (2012) 2031-2050.

[13] M. González-Pleiter, S. Gonzalo, I. Rodea-Palomares, F. Leganés, R. Rosal, K. Boltes, E. Marco, F. Fernández-Piñas, Toxicity of five antibiotics and their mixtures towards photosynthetic aquatic organisms: implications for environmental risk assessment, Water Res. 47 (2013) 2050-2064.

[14] J. Boberg, C. Taxvig, S. Christiansen, U. Hass, Possible endocrine disrupting effects of parabens and their metabolites, Reprod. Toxicol. 30 (2010) 301-312.

[15] S. Terasaka, A. Inoue, M. Tanji, R. Kiyama, Expression profiling of estrogen-responsive genes in breast cancer cells treated with alkylphenols chlorinated phenols, parabens, or bis- and benzoylphenols for evaluation of estrogenic activity, Toxicol. Lett. 163 (2006) 130-141.

[16] J. Chen, K.C. Ahn, N.A. Gee, S.J. Gee, B.D. Hammock, B.L. Lasley, Antiandrogenic properties of parabens and other phenolic containing small molecules in personal care products, Toxicol. Appl. Pharm. 221 (2007) 278-284.

[17] R.S. Tavares, F.C. Martins, P.J. Oliveira, J. Ramalho-Santos, F.P. Peixoto, Parabens in male infertility-is there a mitochondrial connection, Reprod. Toxicol. 27 (2009) 1-7.

[18] P.D. Darbre, A. Aljarrah, W.R. Miller, N.G. Coldham, M.J. Sauer, G.S. Pope, Concentrations of parabens in human breast tumours, J. Appl. Toxicol. 24 (2004) 5-13.

[19] A.R. Scialli, Reproductive effects of the parabens, Reprod. Toxicol. 32 (2011) 138-140.

[20] H. Yamamoto, I. Tamura, Y. Hirata, J. Kato, K. Kagota, S. Katsuki, N. Tatarazako, Aquatic toxicity and ecological risk assessment of seven parabens: individual and additive approach, Sci. Total Environ. 410 (2011) 102-111.

[21] M.M. Huber, A. Göbel, A. Joss, N. Hermann, D. Löffler, C.S. McArdell, U. von Gunten, Oxidation of pharmaceuticals during ozonation of municipal wastewater effluents: a pilot study, Environ. Sci. Technol. 39 (2005) 4290-4299.

[22] J. Hollender, S.G. Zimmermann, S. Koepke, M. Krauss, C.S. McArdell, C. Ort, H. Singer, U. von Gunten, H. Siegrist, Elimination of organic micropollutants in a municipal wastewater treatment plant upgraded with a full-scale postozonation followed by sand filtration, Environ. Sci. Technol. 43 (2009) $7862-7869$.

[23] C. von Sonntag, U. von Gunten, Chemistry of Ozone in Water and Wastewater Treatment: From Basic Principles to Applications, IWA Publishing, London, 2012.

[24] Y. Lee, L. Kovalova, C.S. McArdell, U. Von Gunten, Prediction of micropollutant elimination during ozonation of a hospital wastewater effluent, Water Res. 64 (2014) 134-148.
[25] M.S. Elovitz, U. von Gunten, Hydroxyl radical/ozone ratios during ozonation processes. I. The $R_{\mathrm{ct}}$ concept, Ozone-Sci. Eng. 21 (1999) 239-260.

[26] C. Prasse, D. Stalter, U. Schulte-Oehlmann, J. Oehlmann, T.A. Ternes, Spoilt for choice: a critical review on the chemical and biological assessment of current wastewater treatment technologies, Water Res. (2015), http://dx.doi.org/10. 1016/j.watres.2015.09.023.

[27] T.A. Ternes, J. Stuber, N. Herrmann, D. McDowell, A. Ried, M. Kampmann, B. Teiser, Ozonation: a tool for removal of pharmaceuticals, contrast media and musk fragrances from wastewater? Water Res. 37 (2003) 1976-1982.

[28] A.Y.C. Lin, C.F. Lin, J.M. Chiou, P.A. Hong, $\mathrm{O}_{3}$ and $\mathrm{O}_{3} / \mathrm{H}_{2} \mathrm{O}_{2}$ treatment of sulfonamide and macrolide antibiotics in wastewater, J. Hazard. Mater. 171 (2009) 452-458.

[29] K.S. Tay, N.A. Rahman, M.R.B. Abas, Ozonation of parabens in aqueous solution: kinetics and mechanism of degradation, Chemosphere 81 (2010) 1446-1453.

[30] L.S. Clesceri, A.E. Greenberg, A.D. Eaton, Standard Methods for the Examination of Water and Wastewater, 20th ed., American Public Health Association, American Water Works Association, Water Environment Federation, Baltimore, Maryland, 1998.

[31] I. Michael-Kordatou, M. Iacovou, Z. Frontistis, E. Hapeshi, D.D. Dionysiou, D. Fatta-Kassinos, Erythromycin oxidation and ERY-resistant Escherichia coli inactivation in urban wastewater by sulfate radical-based oxidation process under UV-C irradiation, Water Res. 85 (2015) 346-358.

[32] H. Bader, J. Hoigne, Determination of ozone in water by the indigo method, Water Res. 15 (1981) 449-456.

[33] I. Michael, E. Hapeshi, C. Michael, A.R. Varela, S. Kyriakou, C. Manaia, D. Fatta-Kassinos, Effectiveness of solar Fenton process on abatement of antibiotics at a pilot plant scale: degradation kinetics, ecotoxicity assessment and removal of antibiotic resistant enterococci, Water Res. 46 (2012) 5621-5634.

[34] J.M. Andrews, BSAC standardized disc susceptibility testing method (version 8), J. Antimicrob. Chemother. 64 (2009) 454-489.

[35] M.M. Huber, S. Canonica, G.Y. Park, U. Von Gunten, Oxidation of pharmaceuticals during ozonation and advanced oxidation processes, Environ. Sci. Technol. 37 (2003) 1016-1024.

[36] M.G. Antoniou, G. Hey, S.R. Vega, A. Spiliotopoulou, J. Fick, M. Tysklind, H.R. Andersen, Required ozone doses for removing pharmaceuticals from wastewater effluents, Sci. Total Environ. 456 (2013) 42-49.

[37] J. Rivas, O. Gimeno, A. Encinas, F. Beltrán, Ozonation of the pharmaceutical compound ranitidine: reactivity and kinetic aspects, Chemosphere 76 (2009) 651-656.

[38] S.A. Snyder, E.C. Wert, D.J. Rexing, R.E. Zegers, D.D. Drury, Ozone oxidation of endocrine disruptors and pharmaceuticals in surface water and wastewater, Ozone-Sci. Eng. 28 (2006) 445-460.

[39] I.A. Balcıoğlu, M. Ötker, Treatment of pharmaceutical wastewater containing antibiotics by $\mathrm{O}_{3}$ and $\mathrm{O}_{3} / \mathrm{H}_{2} \mathrm{O}_{2}$ processes, Chemosphere 50 (2003) 85-95.

[40] R.F. Dantas, S. Contreras, C. Sans, S. Esplugas, Sulfamethoxazole abatement by means of ozonation, J. Hazard. Mater. 150 (2008) 790-794.

[41] K. Li, A. Yediler, M. Yang, S. Schulte-Hostede, M.H. Wong, Ozonation of oxytetracycline and toxicological assessment of its oxidation by-products, Chemosphere 72 (2008) 473-478.

[42] T. Angelov, A. Vlasenko, W. Tashkov, HPLC determination of $\mathrm{pK}_{\mathrm{a}}$ of parabens and investigation on their lipophilicity parameters, J. Liq. Chromatogr. Relat Technol. 31 (2008) 188-197.

[43] B. De Witte, H. Van Langenhove, K. Demeestere, K. Saerens, P. De Wispelaere, J. Dewulf, Ciprofloxacin ozonation in hospital wastewater treatment plant effluent: effect of $\mathrm{pH}$ and $\mathrm{H}_{2} \mathrm{O}_{2}$, Chemosphere 78 (2010) 1142-1147.

[44] M. Petala, P. Samaras, A. Zouboulis, A. Kungolos, G.P. Sakellaropoulos, Influence of ozonation on the in vitro mutagenic and toxic potential of secondary effluents, Water Res. 42 (2008) 4929-4940.

[45] F.J. Benitez, J.L. Acero, F.J. Real, G. Roldán, Ozonation of pharmaceutical compounds: rate constants and elimination in various water matrices, Chemosphere 77 (2009) 53-59.

[46] U. Von Gunten, Ozonation of drinking water: part II. Disinfection and by-product formation in presence of bromide iodide or chlorine, Water Res. 37 (2003) 1469-1487.

[47] $98 / 83 / E C$, Council Directive on the quality of water intended for human consumption, 1998.

[48] M.O. Buffle, S. Galli, U. Von Gunten, Enhanced bromate control during ozonation: the chlorine-ammonia process, Environ. Sci. Technol. 38 (2004) 5187-5195.

[49] E. Haghedooren, K.K.R.B.V.S. Raju, P. Dehouck, C. Govaerts, A. Van Schepdael, J. Hoogmartens, E. Adams, Investigation of degradation products in a topical gel containing erythromycin and benzoyl peroxide by liquid chromatography-mass spectrometry, J. Pharm. Biomed. Anal. 41 (2006) $165-175$.

[50] M. Llorca, S. Rodríguez-Mozaz, O. Couillerot, K. Panigoni, J. de Gunzburg, S. Bayer, R. Czaja, D. Barceló, Identification of new transformation products during enzymatic treatment of tetracycline and erythromycin antibiotics at laboratory scale by an on-line turbulent flow liquid-chromatography coupled to a high resolution mass spectrometer LTQ-Orbitrap, Chemosphere 119 (2015) 90-98.

[51] H. Fang, Y. Gao, G. Li, J. An, P.K. Wong, H. Fu, T. An, Advanced oxidation kinetics and mechanism of preservative propylparaben degradation in aqueous suspension of $\mathrm{TiO}_{2}$ and risk assessment of its degradation products, Environ. Sci. Technol. 47 (2013) 2704-2712. 
[52] X. Feng, Y. Chen, Y. Fang, X. Wang, Z. Wang, T. Tao, Y. Zuo, Photodegradation of parabens by $\mathrm{Fe}(\mathrm{III})$-citrate complexes at circumneutral $\mathrm{pH}$ : Matrix effect and reaction mechanism, Sci. Total Environ. 472 (2014) 130-136.

[53] T. Velegraki, E. Hapeshi, D. Fatta-Kassinos, I. Poulios, Solar-induced heterogeneous photocatalytic degradation of methyl-paraben, Appl. Catal. B 178 (2014) 2-11.

[54] R. Daghrir, A. Dimboukou-Mpira, B. Seyhi, P. Drogui, Photosonochemical degradation of butyl-paraben: optimization, toxicity and kinetic studies, Sci. Total Environ. 490 (2014) 223-234.

[55] D. Stalter, A. Magdeburg, J. Oehlmann, Comparative toxicity assessment of ozone and activated carbon treated sewage effluents using an in vivo test battery, Water Res. 44 (2010) 2610-2620.

[56] D. Stalter, A. Magdeburg, M. Weil, T. Knacker, J. Oehlmann, Toxication or detoxication? In vivo toxicity assessment of ozonation as advanced wastewater treatment with the rainbow trout, Water Res. 44 (2010) 439-448.

[57] D. Altmann, H. Schaar, C. Bartel, D.L.P. Schorkopf, I. Miller, N. Kreuzinger, B. Grillitsch, Impact of ozonation on ecotoxicity and endocrine activity of tertiary treated wastewater effluent, Water Res. 46 (2012) 3693-3702.
[58] P. Xu, M.L. Janex, P. Savoye, A. Cockx, V. Lazarova, Wastewater disinfection by ozone: main parameters for process design, Water Res. 36 (2002) 1043-1055.

[59] F. Lüddeke, S. Heß, C. Gallert, J. Winter, H. Güde, H. Löffler, Removal of total and antibiotic resistant bacteria in advanced wastewater treatment by ozonation in combination with different filtering techniques, Water Res. 69 (2015) 243-251.

[60] A. Luczkiewicz, K. Jankowska, S. Fudala-Ksiazek, K. Olanczuk-Neyman, Antimicrobial resistance of fecal indicators in municipal wastewater treatment plant, Water Res. 44 (2010) 5089-5097.

[61] N.B. Öncü, Y.Z. Menceloğlu, I.A. Balcıoğlu, Comparison of the effectiveness of chlorine, ozone, and photocatalytic disinfection in reducing the risk of antibiotic resistance pollution, J. Adv. Oxid. Technol. 14 (2011) 196-203.

[62] H.M. Kuch, K. Ballschmiter, Determination of endocrine-disrupting phenolic compounds and estrogens in surface and drinking water by HRGC-(NCI)-MS in the picogram per liter range, Environ. Sci. Technol. 35 (2001) 3201-3206. 